Supporting Information

\title{
Iridium Complex Catalyzed C2-Extension of Primary Alcohols with Ethanol via Hydrogen Autotransfer Reaction
}

\author{
Masaki Kobayashi, Satoshi Itoh, Keisuke Yoshimura, Yuya Tsukamoto, and Yasushi \\ Obora* \\ Department of Chemistry and Materials Engineering, Faculty of Chemistry, \\ Materials and Bioengineering, Kansai University, Suita, Osaka 564-8680, Japan \\ Email: obora@kansai-u.ac.jp
}

\section{Table of Contents}

S2-3: C2-extension of 1-hexanol with ethanol under various conditions

S4-7: Control experiments

S8: $\quad$ Proposed reaction mechanism for iridium catalyzed C2-extension of primary alcohol with ethanol

S9: $\quad$ Copies of ${ }^{1} \mathrm{H}\left(400 \mathrm{MHz}, \mathrm{CDCl}_{3}\right)$ and ${ }^{13} \mathrm{C}\left\{{ }^{1} \mathrm{H}\right\}$ NMR spectra for 3a

S10: $\quad$ Copies of ${ }^{1} \mathrm{H}\left(400 \mathrm{MHz}, \mathrm{CDCl}_{3}\right)$ and ${ }^{13} \mathrm{C}\left\{{ }^{1} \mathrm{H}\right\}$ NMR spectra for $\mathbf{3 b}$

S11: $\quad$ Copies of ${ }^{1} \mathrm{H}\left(400 \mathrm{MHz}, \mathrm{CDCl}_{3}\right)$ and ${ }^{13} \mathrm{C}\left\{{ }^{1} \mathrm{H}\right\}$ NMR spectra for 3c

S12: $\quad$ Copies of ${ }^{1} \mathrm{H}\left(400 \mathrm{MHz}, \mathrm{CDCl}_{3}\right)$ and ${ }^{13} \mathrm{C}\left\{{ }^{1} \mathrm{H}\right\}$ NMR spectra for 3d

S13: $\quad$ Copies of ${ }^{1} \mathrm{H}\left(400 \mathrm{MHz}, \mathrm{CDCl}_{3}\right)$ and ${ }^{13} \mathrm{C}\left\{{ }^{1} \mathrm{H}\right\}$ NMR spectra for $\mathbf{3 e}$

S14: $\quad$ Copies of ${ }^{1} \mathrm{H}\left(400 \mathrm{MHz}, \mathrm{CDCl}_{3}\right)$ and ${ }^{13} \mathrm{C}\left\{{ }^{1} \mathrm{H}\right\}$ NMR spectra for $3 f$

S15: $\quad$ Copies of ${ }^{1} \mathrm{H}\left(400 \mathrm{MHz}, \mathrm{CDCl}_{3}\right)$ and ${ }^{13} \mathrm{C}\left\{{ }^{1} \mathrm{H}\right\}$ NMR spectra for $\mathbf{3 g}$

S16: Copies of ${ }^{1} \mathrm{H}\left(400 \mathrm{MHz}, \mathrm{CDCl}_{3}\right)$ and ${ }^{13} \mathrm{C}\left\{{ }^{1} \mathrm{H}\right\}$ NMR spectra for $\mathbf{3 h}$

S17: $\quad$ Copies of ${ }^{1} \mathrm{H}\left(400 \mathrm{MHz}, \mathrm{CDCl}_{3}\right)$ and ${ }^{13} \mathrm{C}\left\{{ }^{1} \mathrm{H}\right\}$ NMR spectra for 3i

S18: $\quad$ Copies of ${ }^{1} \mathrm{H}\left(400 \mathrm{MHz}, \mathrm{CDCl}_{3}\right)$ and ${ }^{13} \mathrm{C}\left\{{ }^{1} \mathrm{H}\right\}$ NMR spectra for $\mathbf{3 j}$

S19: $\quad$ Copies of ${ }^{1} \mathrm{H}\left(400 \mathrm{MHz}, \mathrm{CDCl}_{3}\right)$ and ${ }^{13} \mathrm{C}\left\{{ }^{1} \mathrm{H}\right\}$ NMR spectra for $\mathbf{3 k}$

S20: Copies of ${ }^{1} \mathrm{H}\left(400 \mathrm{MHz}, \mathrm{CDCl}_{3}\right)$ and ${ }^{13} \mathrm{C}\left\{{ }^{1} \mathrm{H}\right\}$ NMR spectra for 3I

S21: Copies of ${ }^{1} \mathrm{H}\left(400 \mathrm{MHz}, \mathrm{CDCl}_{3}\right)$ and ${ }^{13} \mathrm{C}\left\{{ }^{1} \mathrm{H}\right\}$ NMR spectra for $\mathbf{5 a}+\mathbf{6 a}$

S22-23: $\quad$ Copies of ${ }^{1} \mathrm{H}\left(400 \mathrm{MHz}, \mathrm{CDCl}_{3}\right)$ and ${ }^{13} \mathrm{C}\left\{{ }^{1} \mathrm{H}\right\}$ NMR spectra for $7 \mathbf{a}+\mathbf{8 a}+9 \mathbf{a}$

S24: $\quad$ Copies of ${ }^{1} \mathrm{H}\left(400 \mathrm{MHz}, \mathrm{CDCl}_{3}\right)$ and ${ }^{13} \mathrm{C}\left\{{ }^{1} \mathrm{H}\right\}$ NMR spectra for $\mathbf{5 b} \mathbf{b} \mathbf{6 b}$

S25: $\quad$ Copies of ${ }^{1} \mathrm{H}\left(400 \mathrm{MHz}, \mathrm{CDCl}_{3}\right)$ and ${ }^{13} \mathrm{C}\left\{{ }^{1} \mathrm{H}\right\}$ NMR spectra for $\mathbf{6 d}$

S26-27: Copies of ${ }^{1} \mathrm{H}\left(400 \mathrm{MHz}, \mathrm{CDCl}_{3}\right)$ and ${ }^{13} \mathrm{C}\left\{{ }^{1} \mathrm{H}\right\}$ NMR spectra for 13a

S28-29: Copies of ${ }^{1} \mathrm{H}\left(400 \mathrm{MHz}, \mathrm{CDCl}_{3}\right)$ and ${ }^{13} \mathrm{C}\left\{{ }^{1} \mathrm{H}\right\}$ NMR spectra for 14a 


\section{C2-extension of 1-hexanol with ethanol under various conditions}

Table S1. Optimization of the reaction conditions

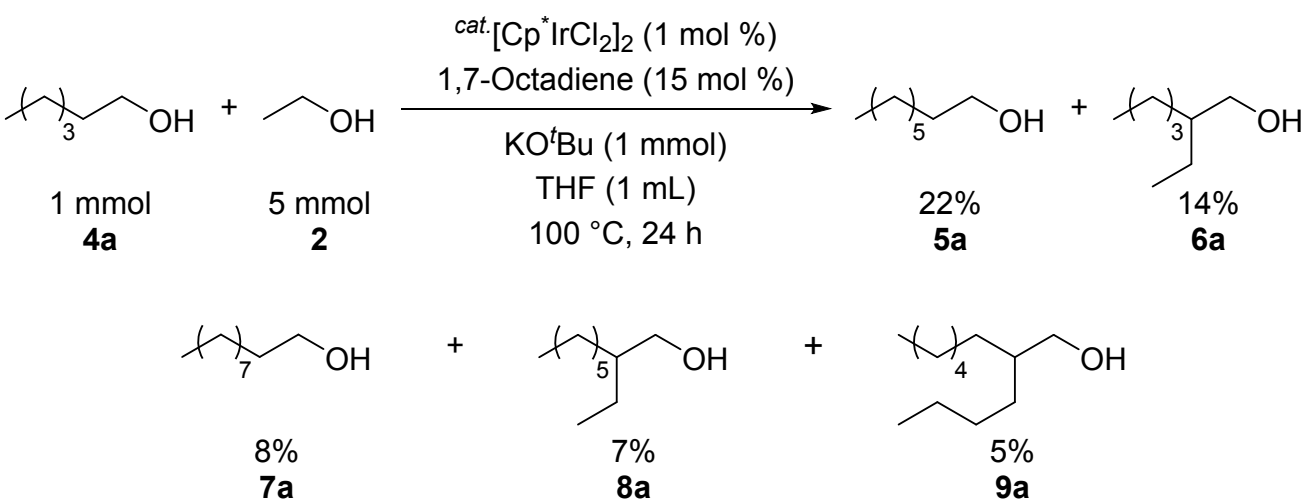

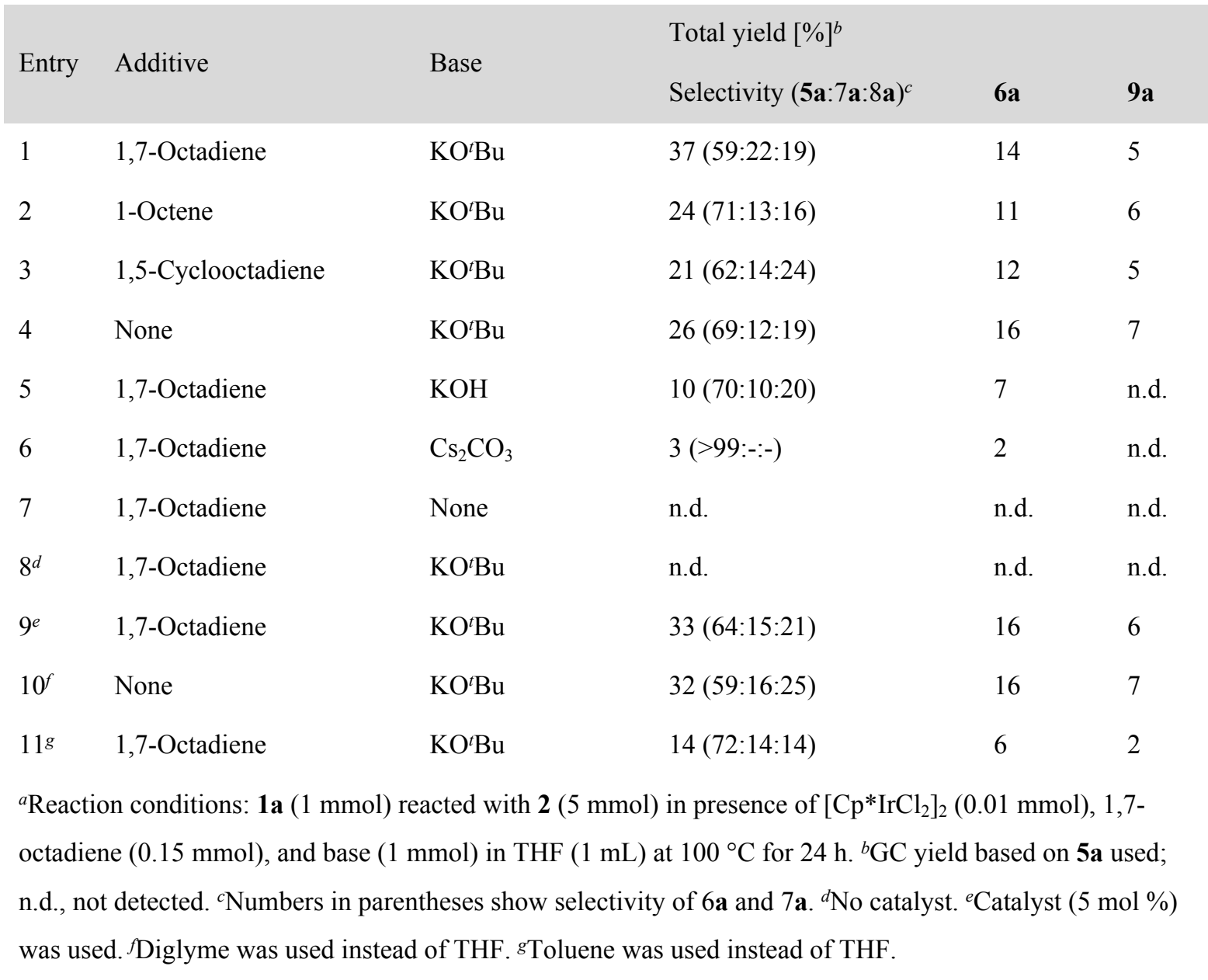



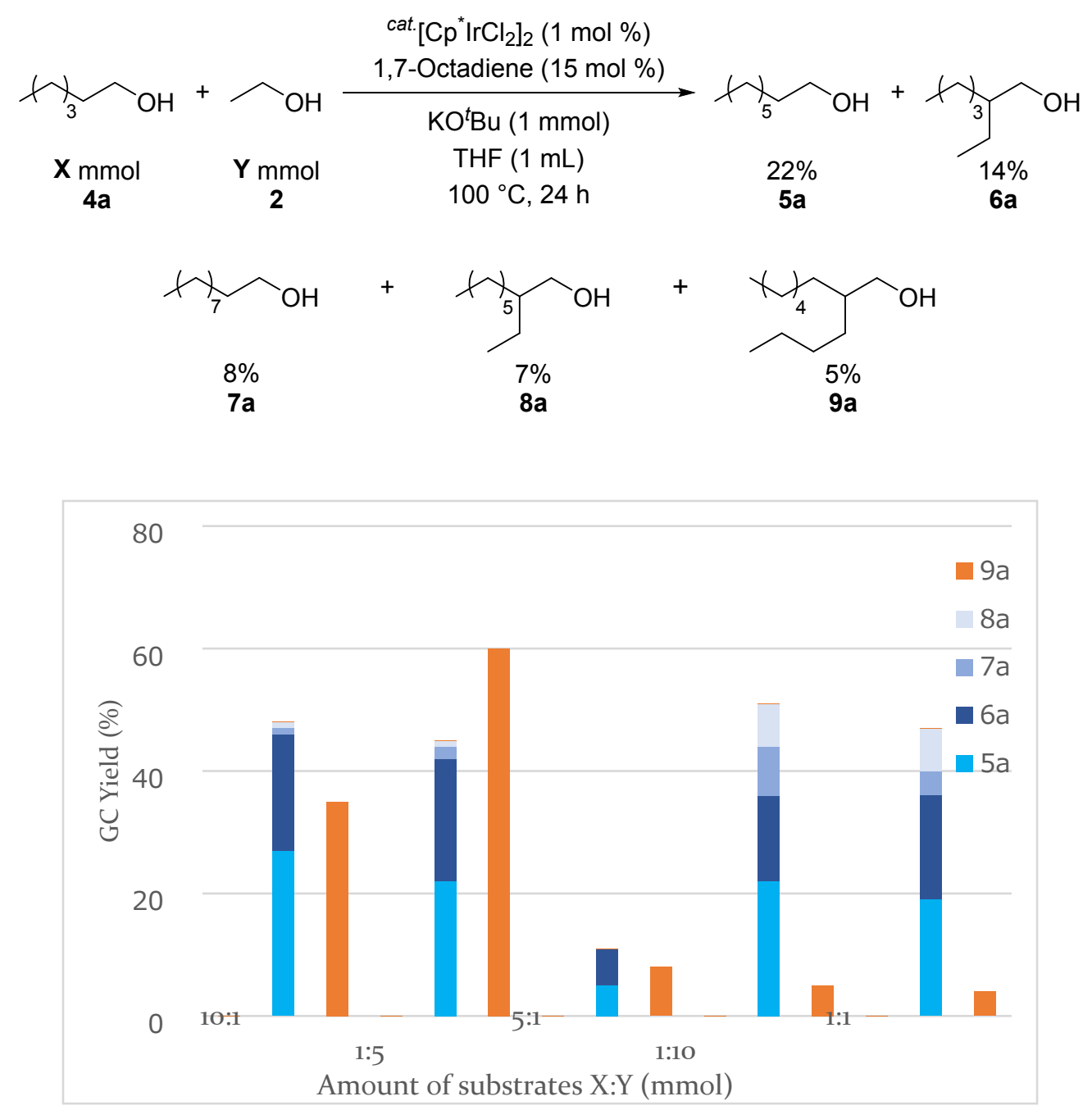

Figure S1. Product distributions for $(5 a+6 a+7 a+8 a: 9 a)$ derived from different substrate ratios of $4 a$ and 2 


\section{Control experiments}

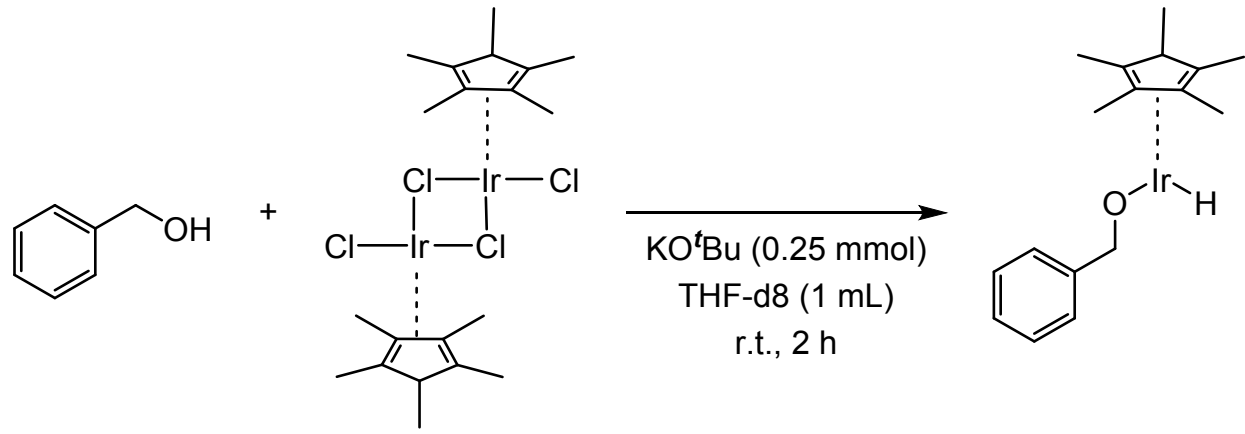
$0.10 \mathrm{mmol}$
$0.10 \mathrm{mmol}$

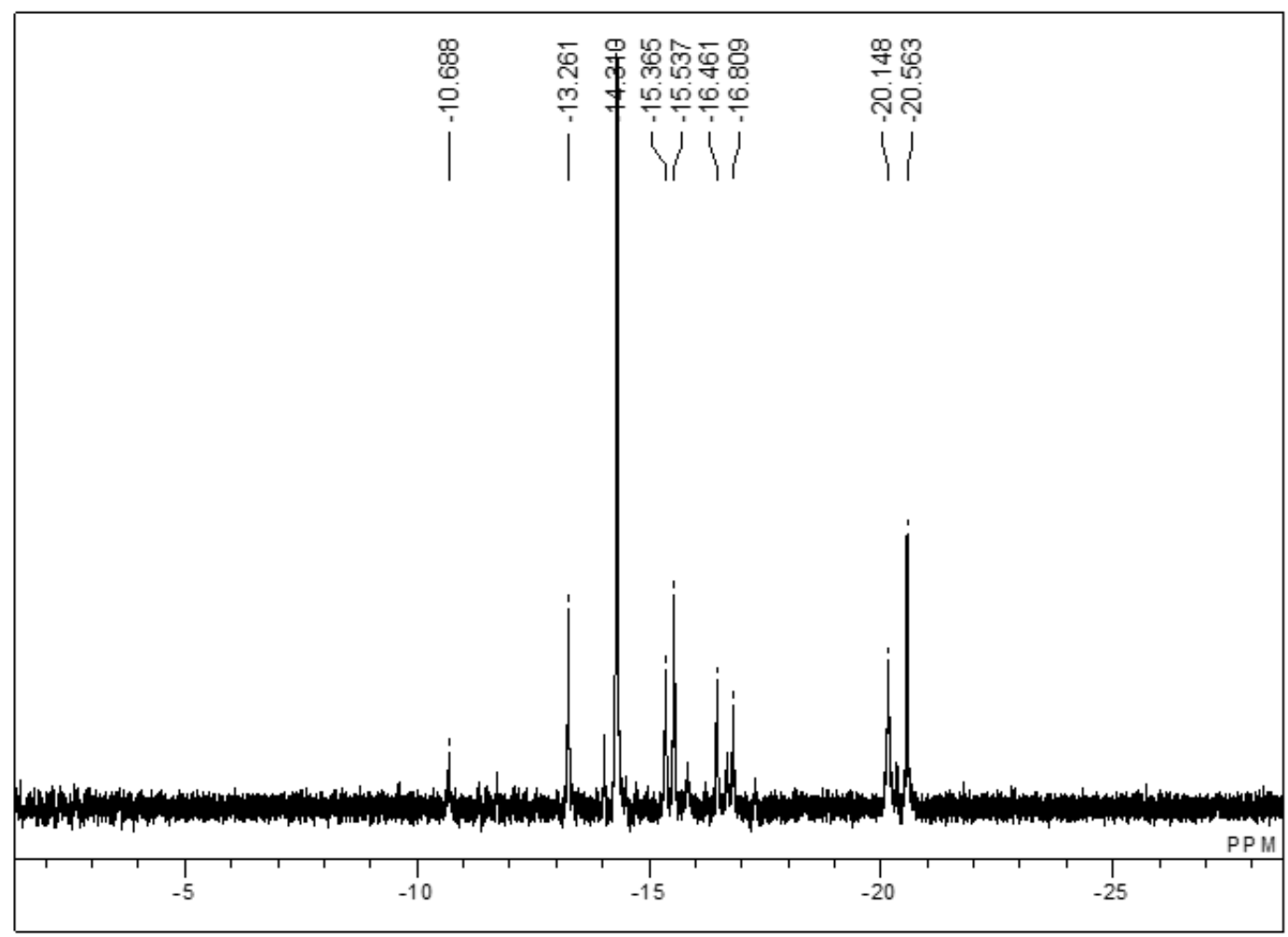

Figure S2. ${ }^{1} \mathrm{H}$ NMR (400 MHz, THF- $d_{g}$ ) spectrum (from $-30 \mathrm{ppm}$ to $0 \mathrm{ppm}$ range) 


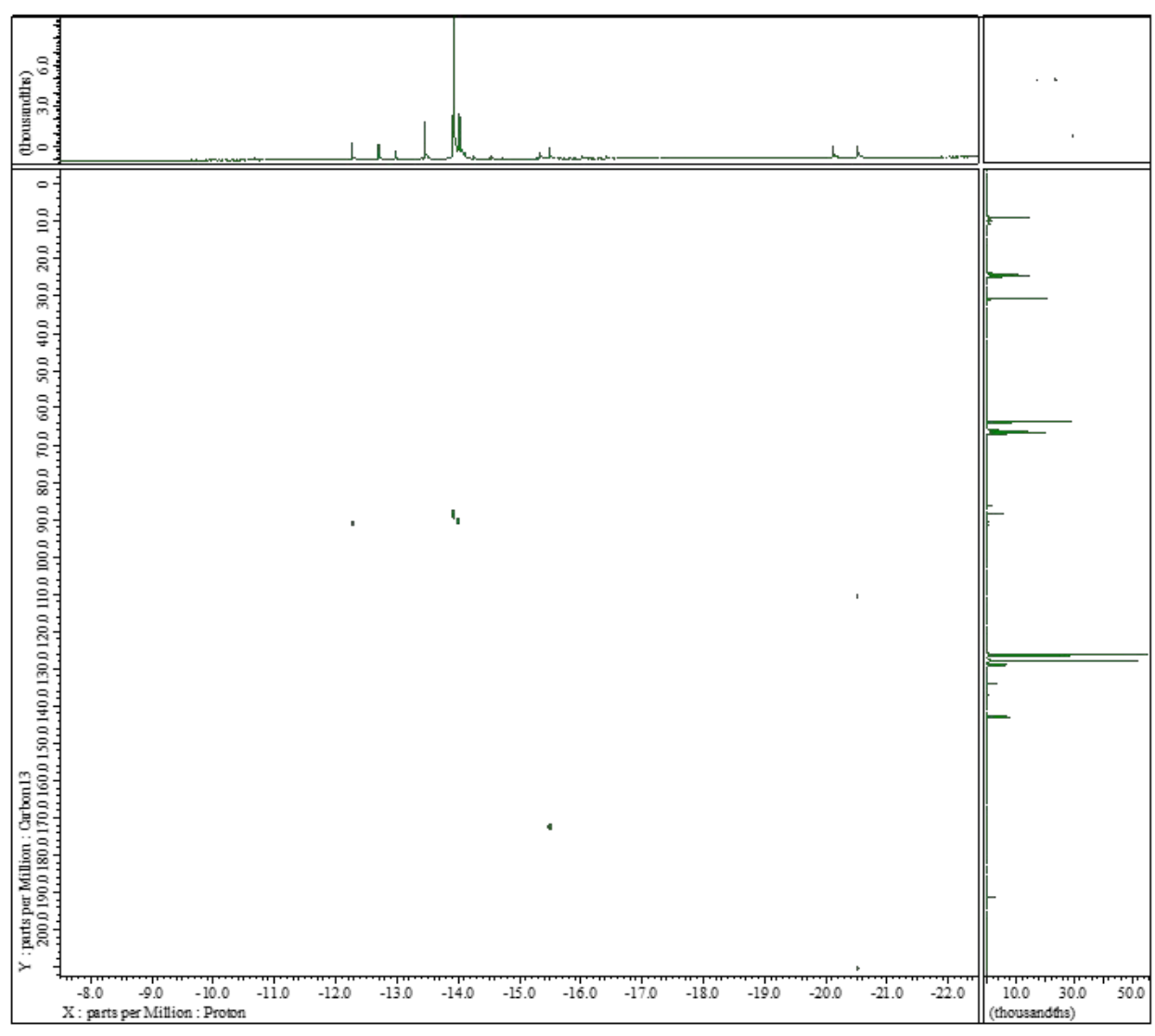

Figure S3. ${ }^{1} \mathrm{H}-{ }^{13} \mathrm{C}$ HMBC spectrum 


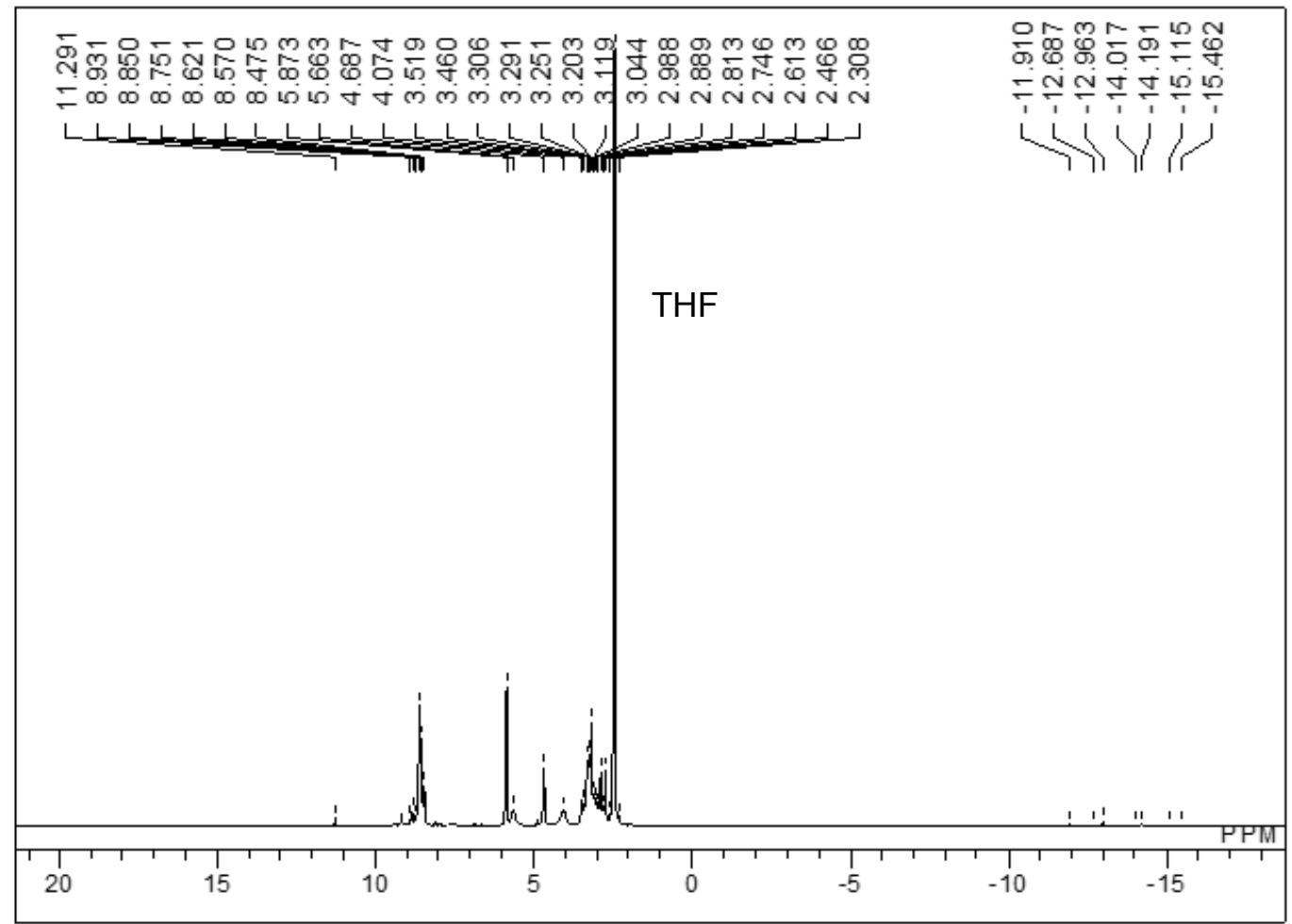

Figure S4. Full ${ }^{1}$ H NMR (400 MHz, THF- $\left.d_{8}\right)$ spectrum 
Scheme S1. C2-extension of benzaldehyde with ethanol<smiles>O=Cc1ccccc1</smiles>

Scheme S2. C2-extension of benzyl alcohol with acetaldehyde

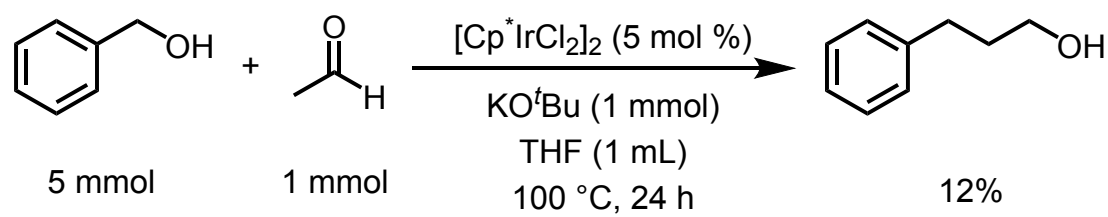

Scheme S3. C2-extension of benzaldehyde with acetaldehyde<smiles>CC(C)=CCc1ccc(CCCO)cc1</smiles>

Scheme S4. C2-extension of benzyl alcohol with ethanol-d $d_{6}$
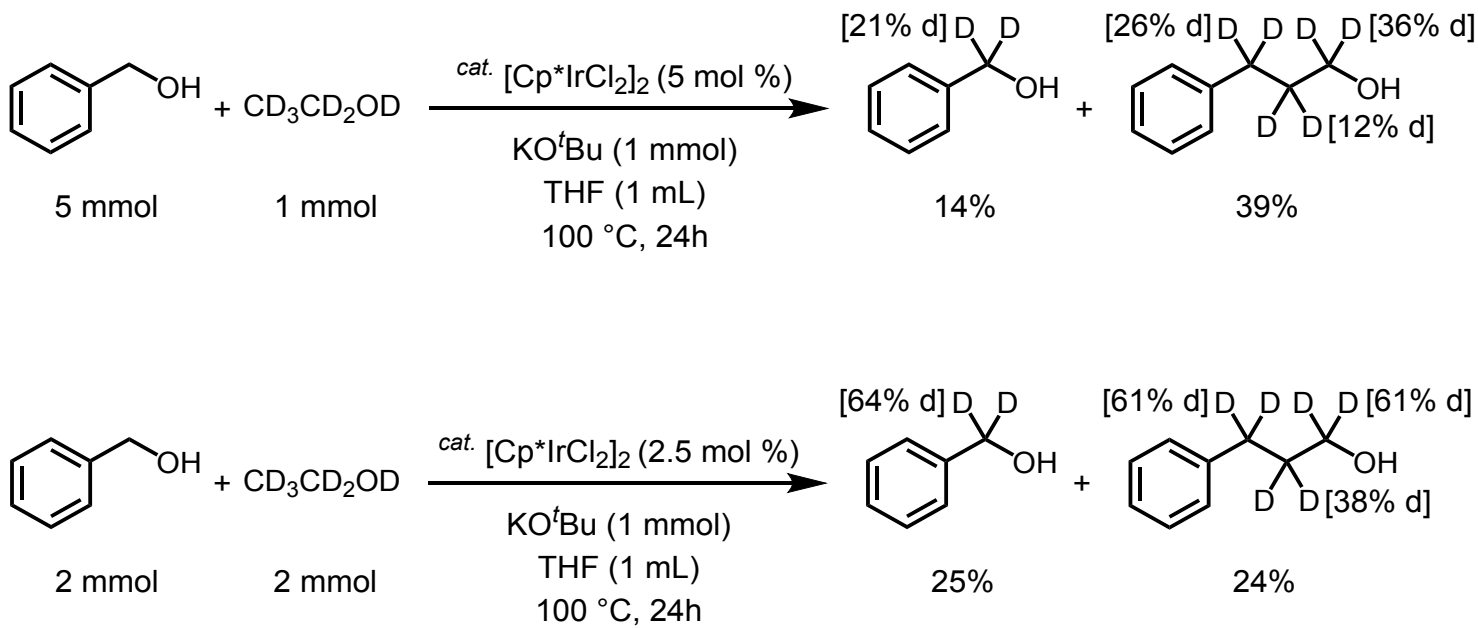
Scheme S5. Proposed reaction mechanism for iridium catalyzed C2-extension of primary alcohol with ethanol
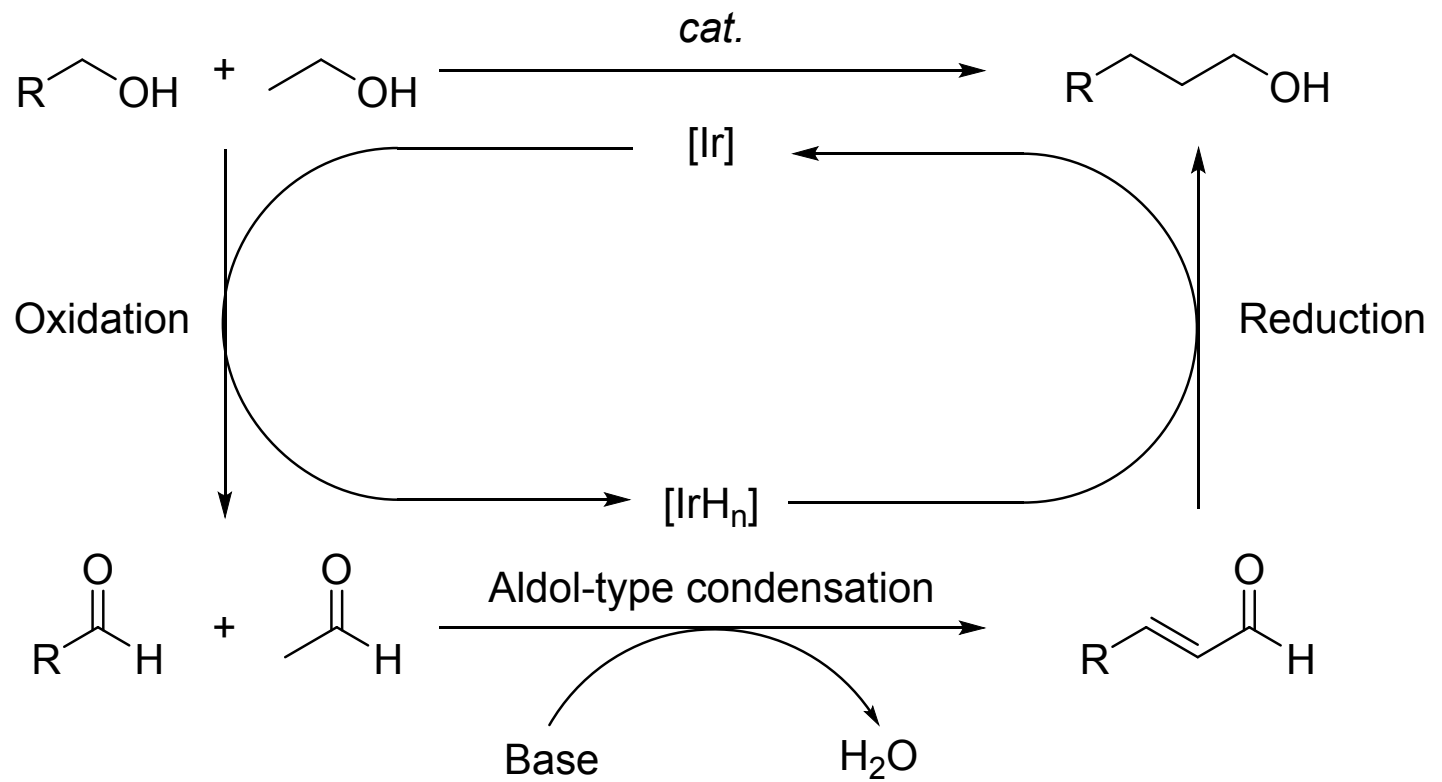


\section{Spectra Data}
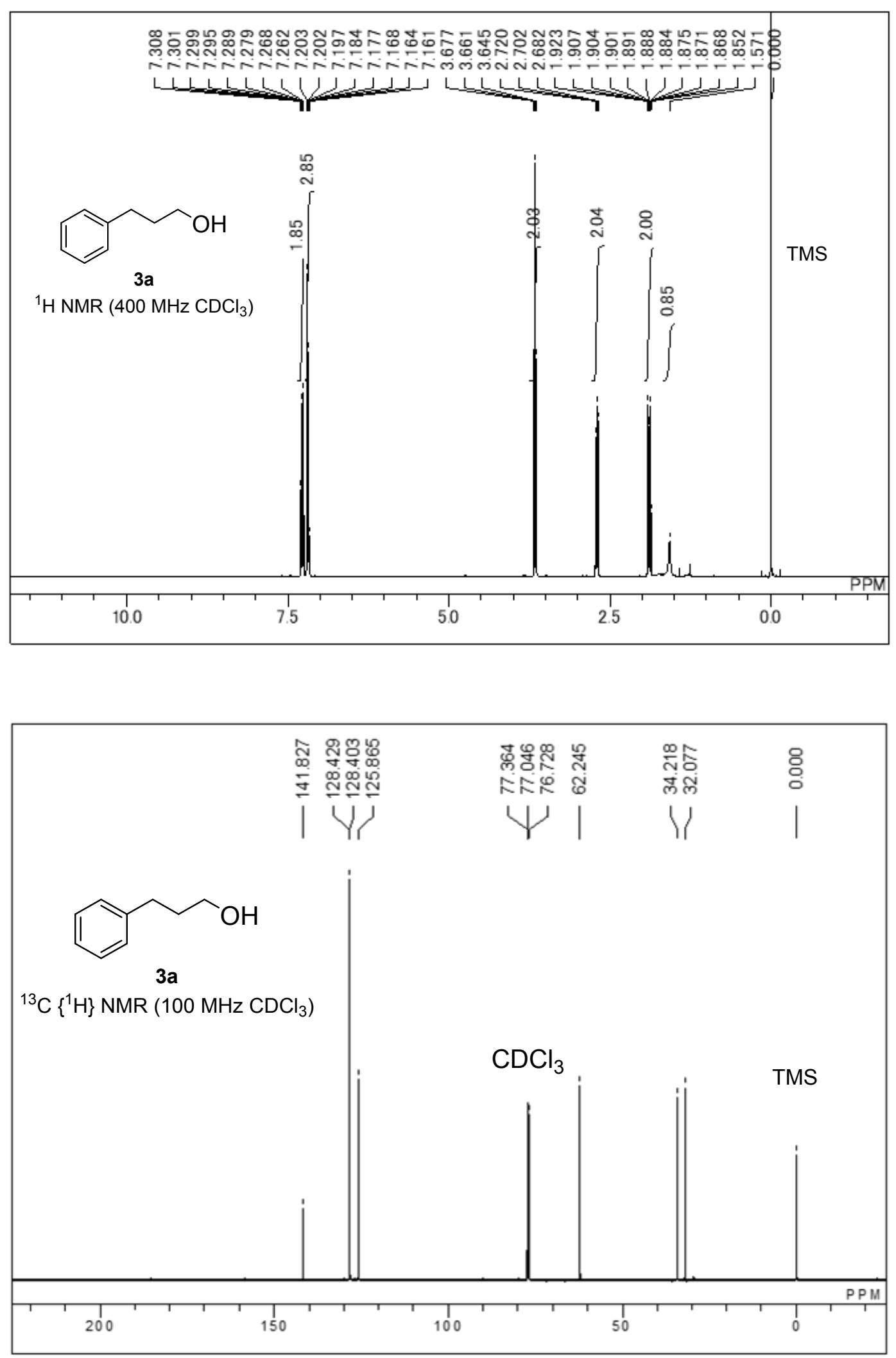

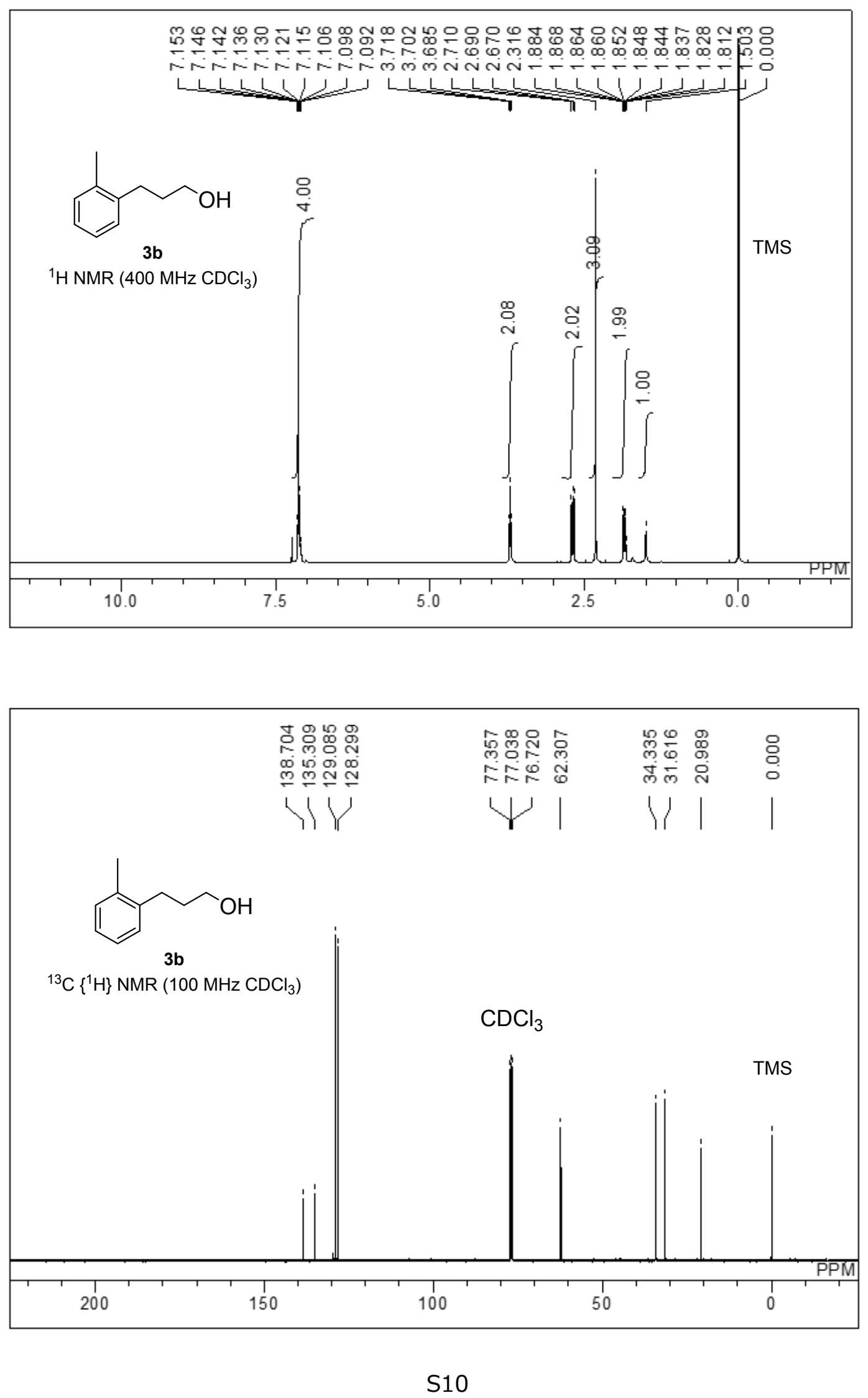

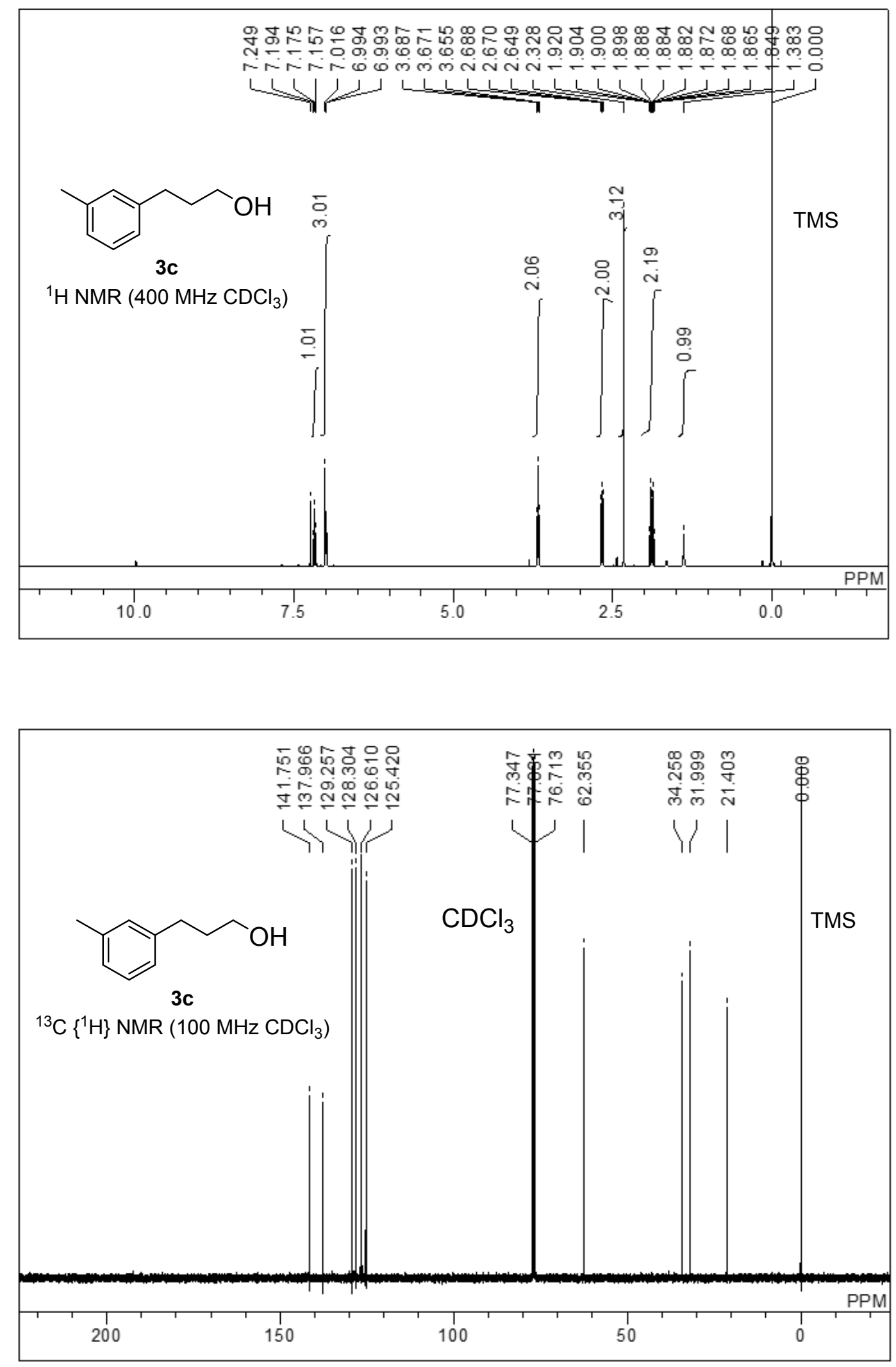

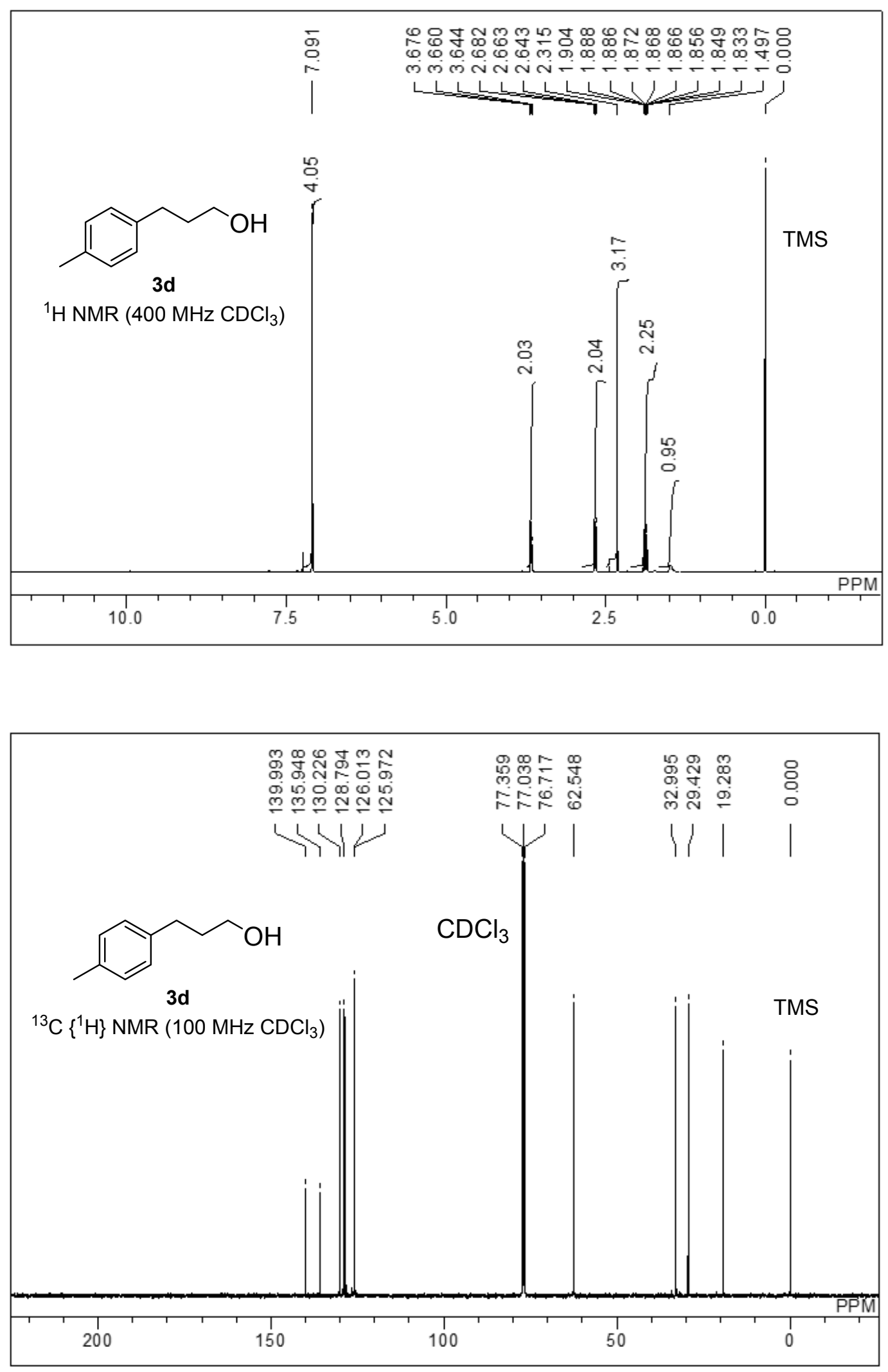

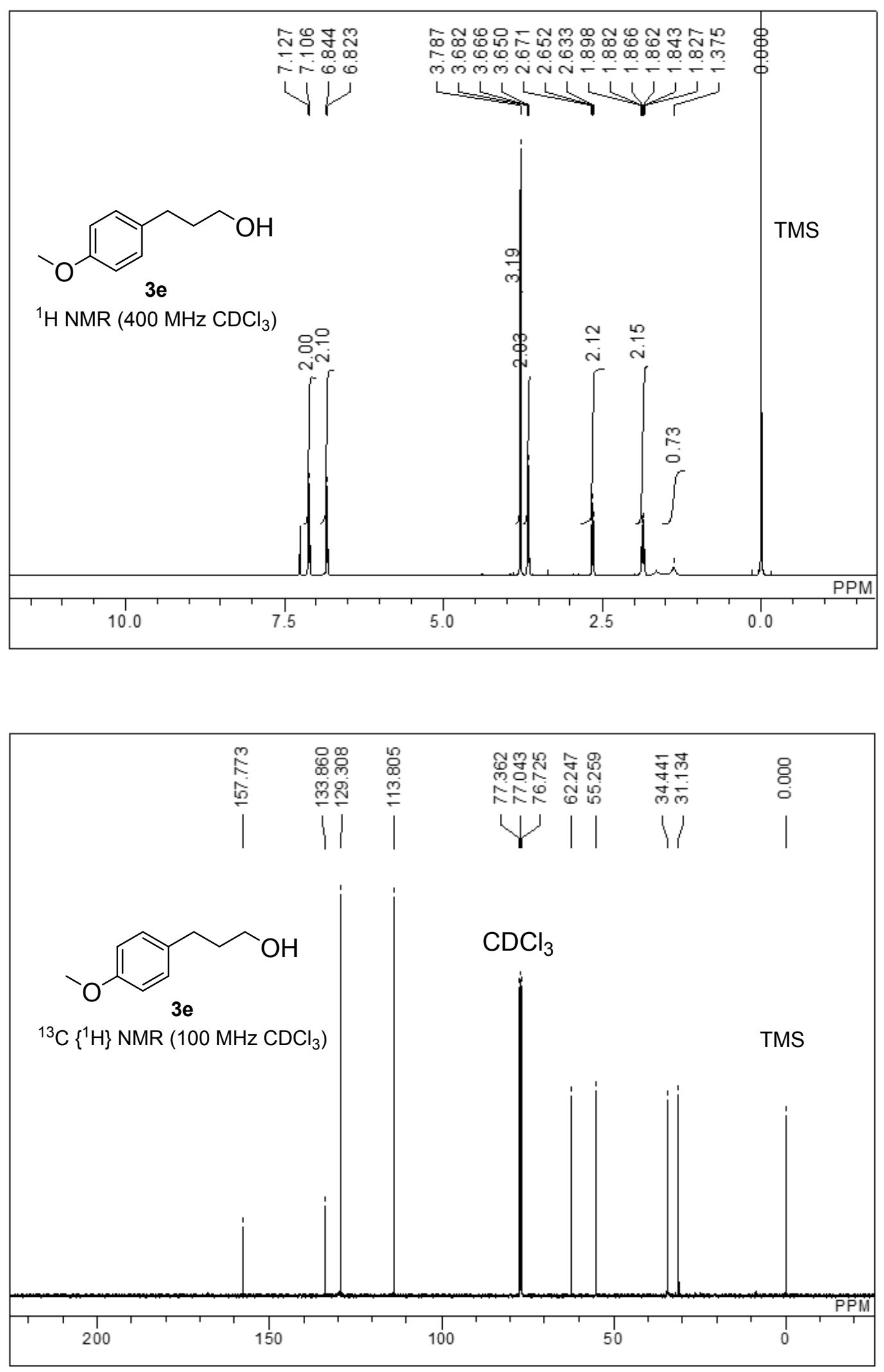

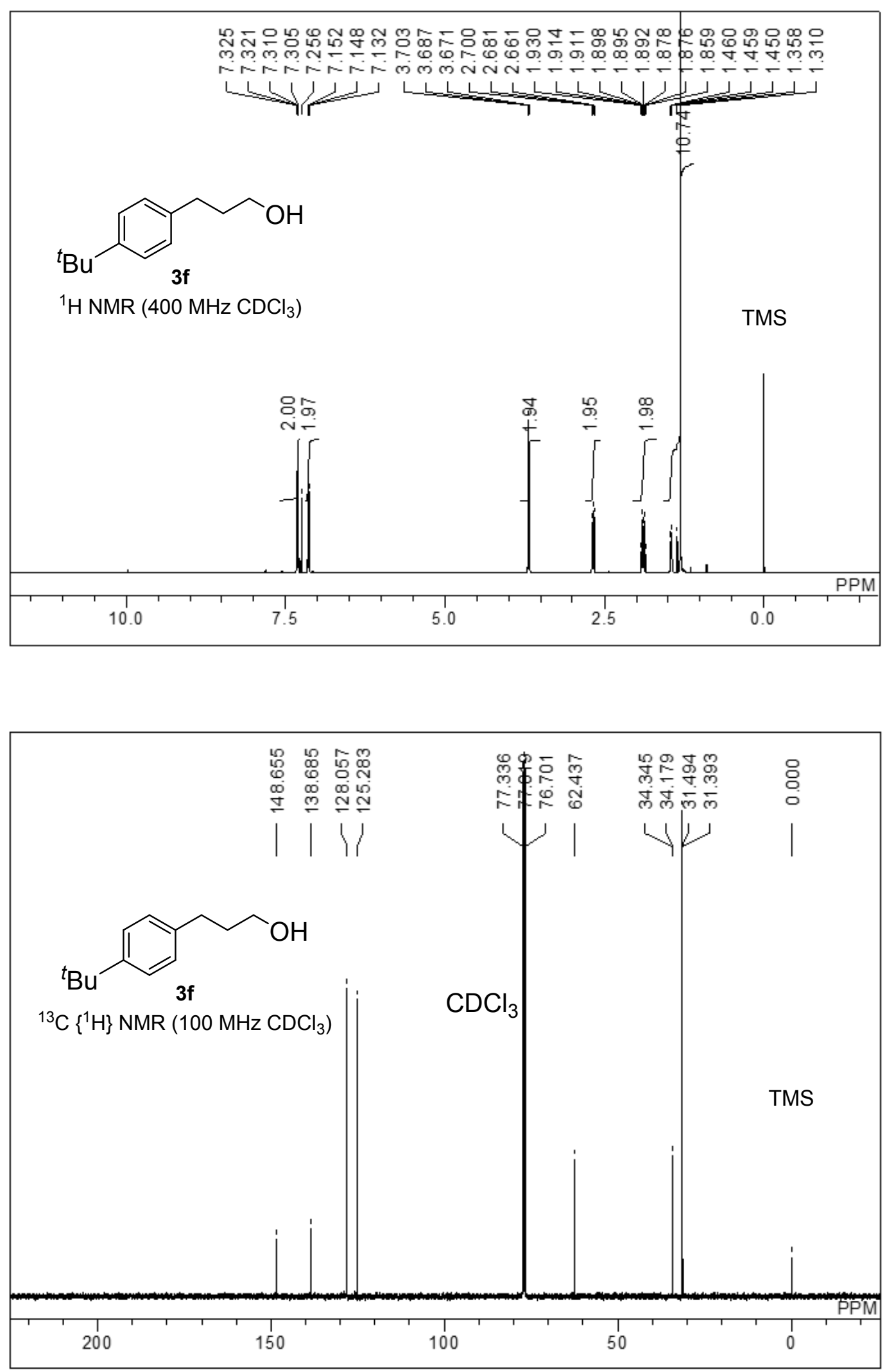

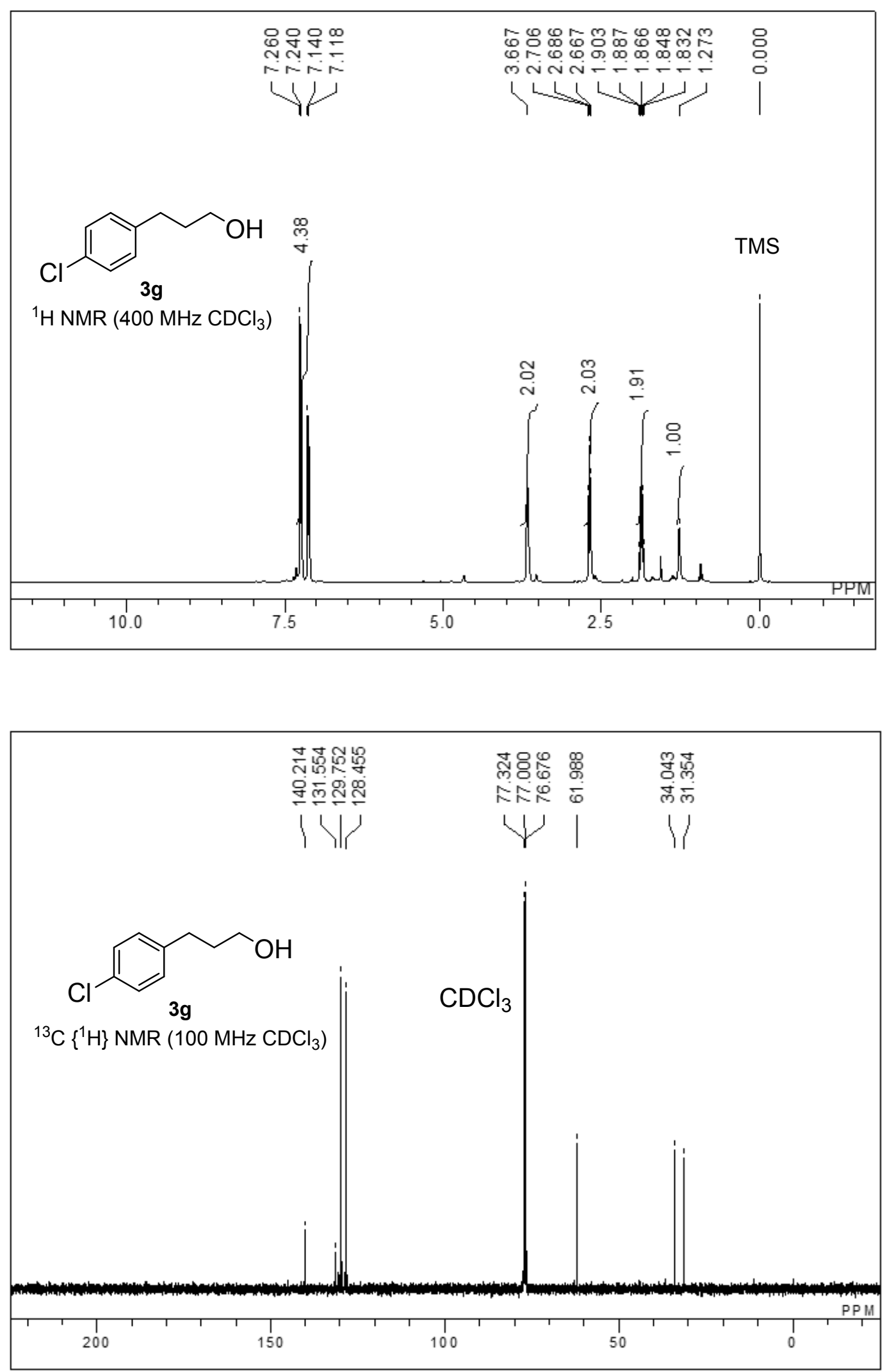

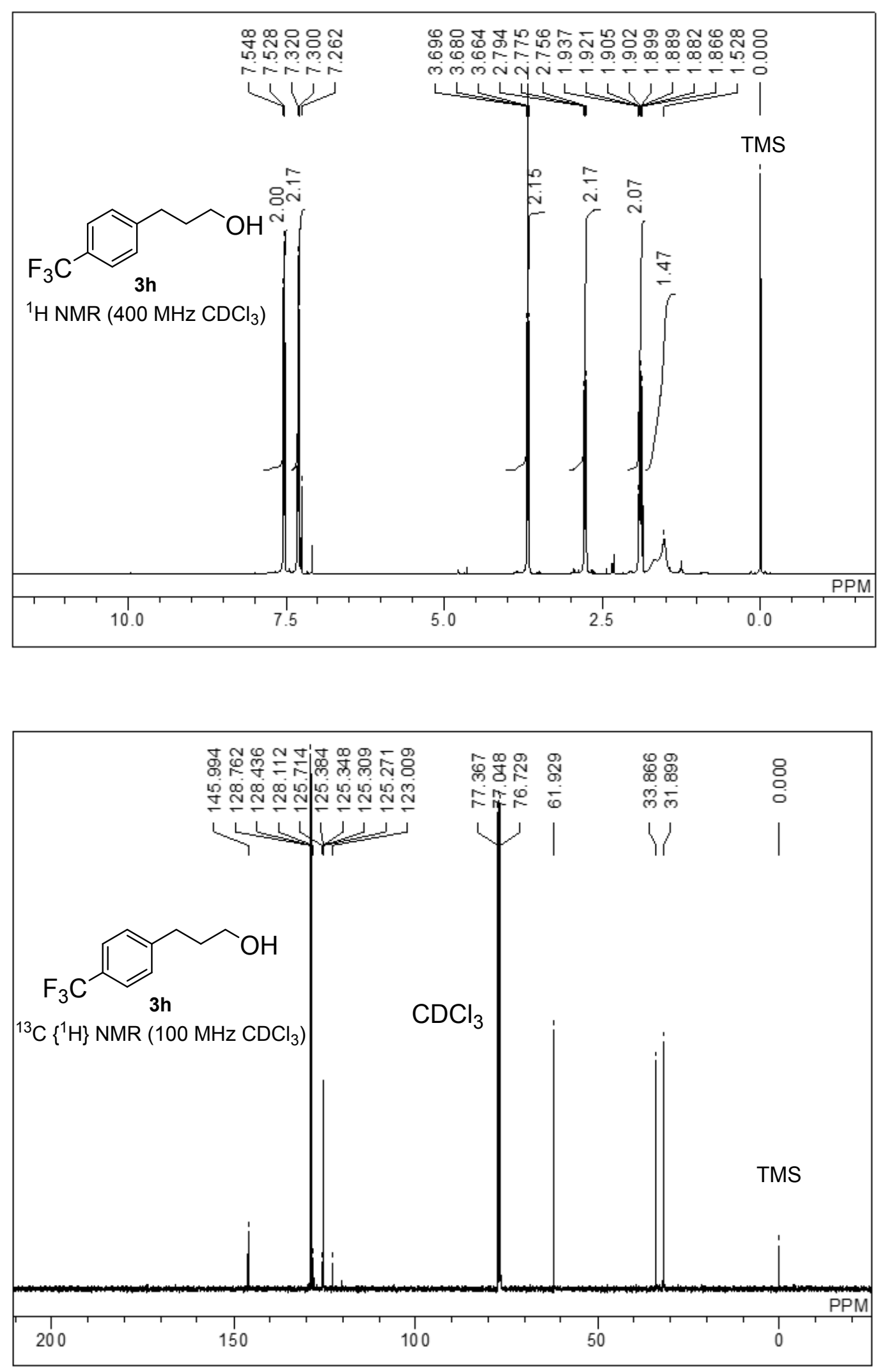

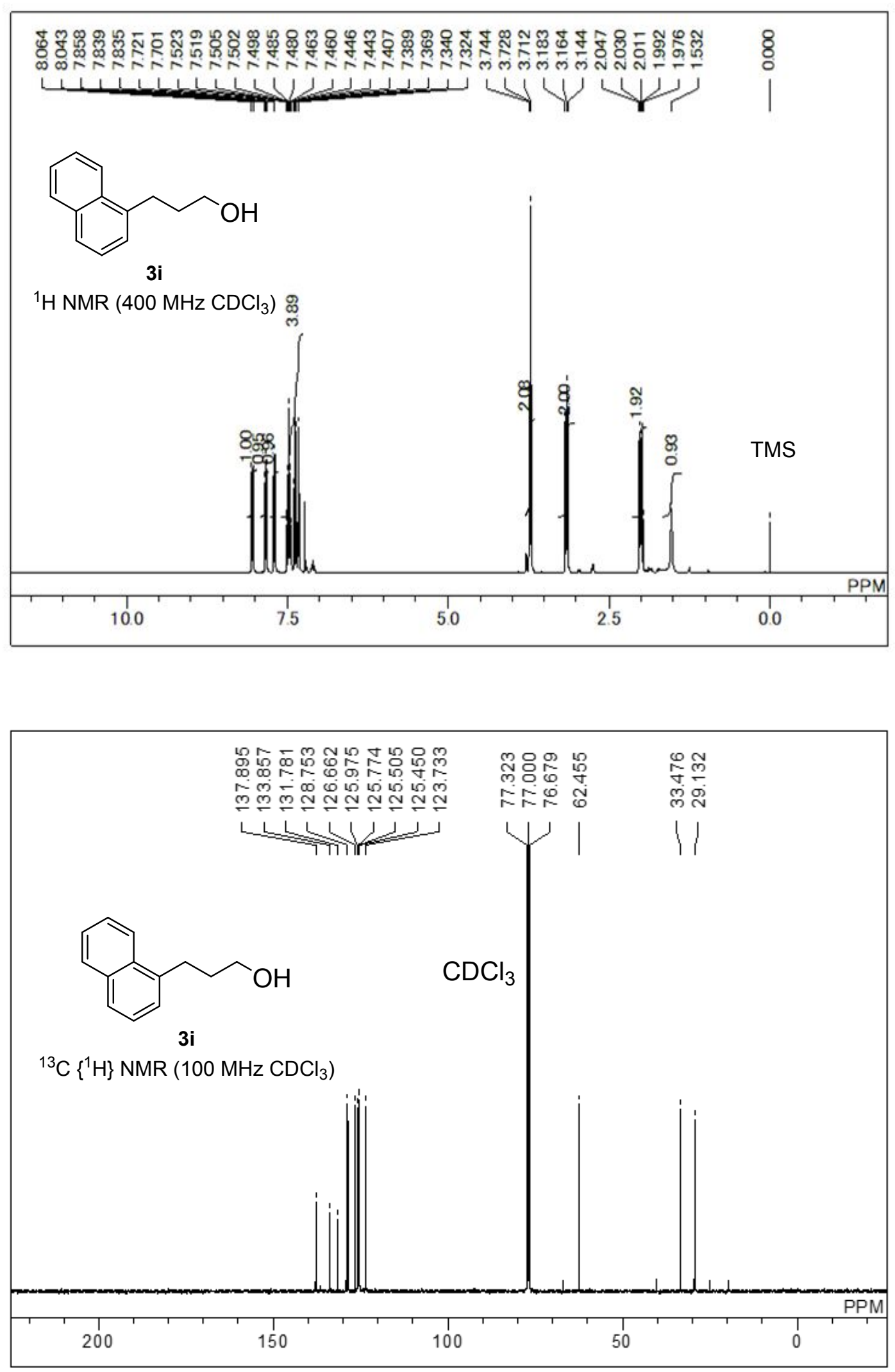

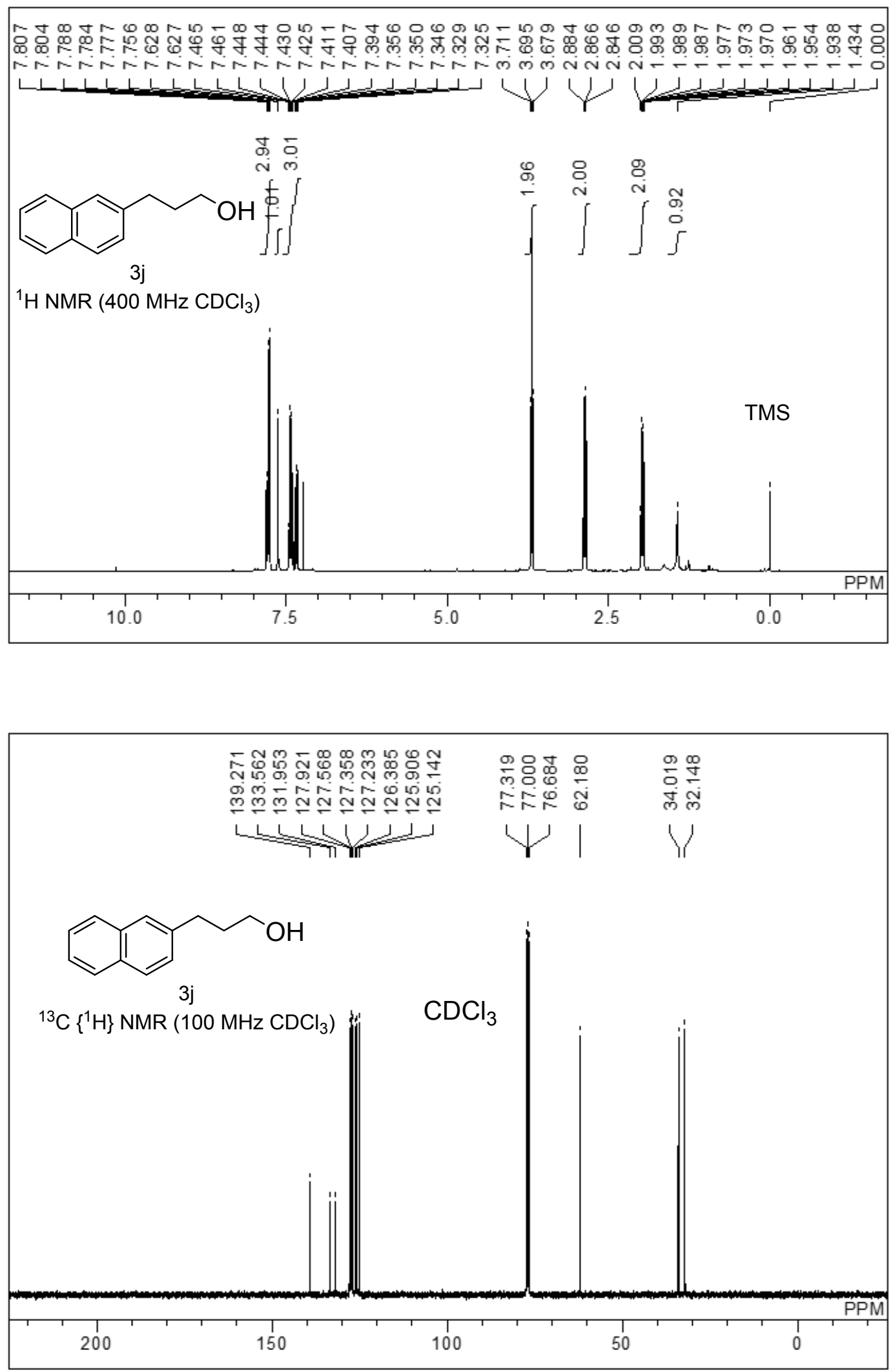

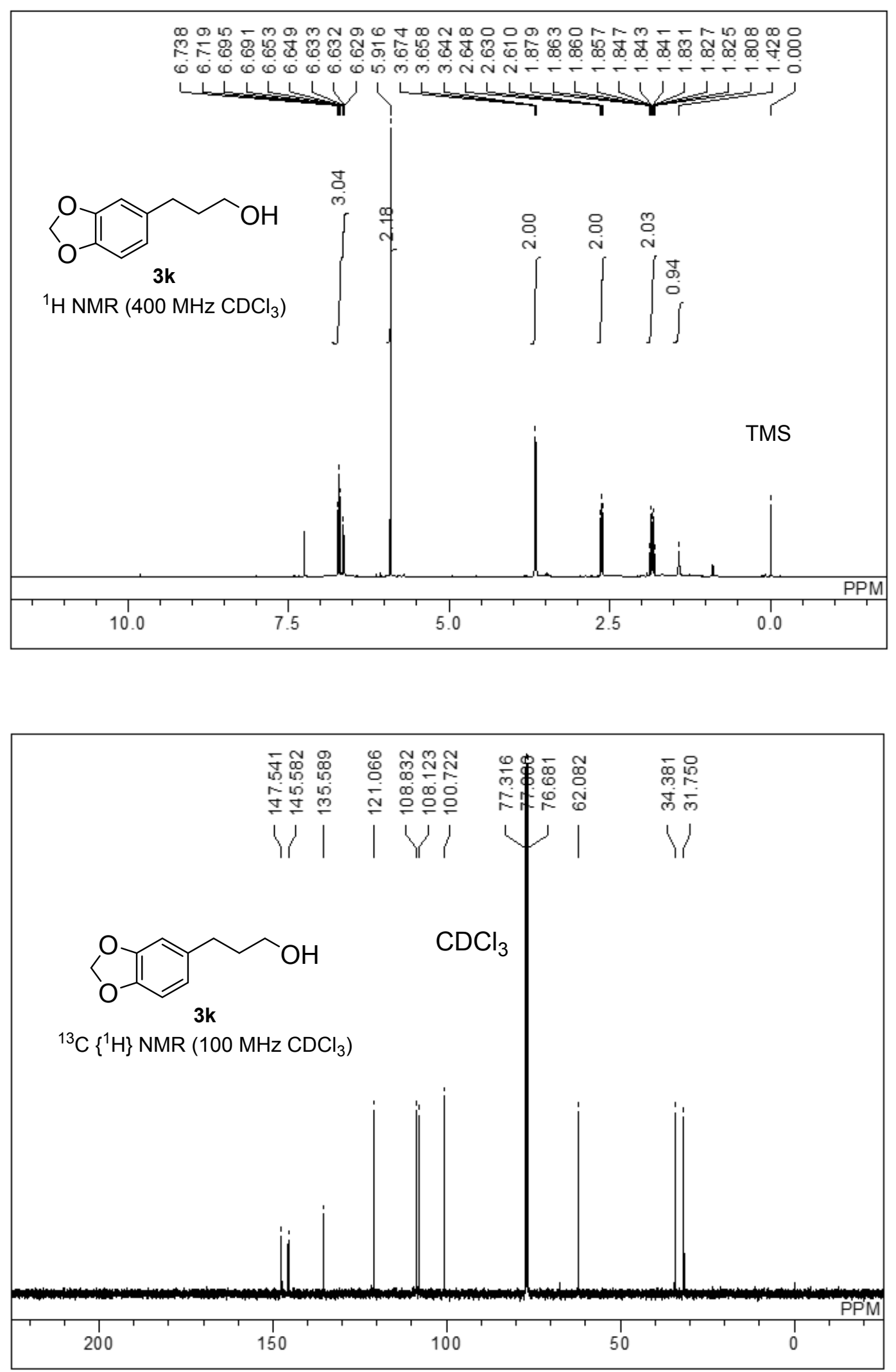

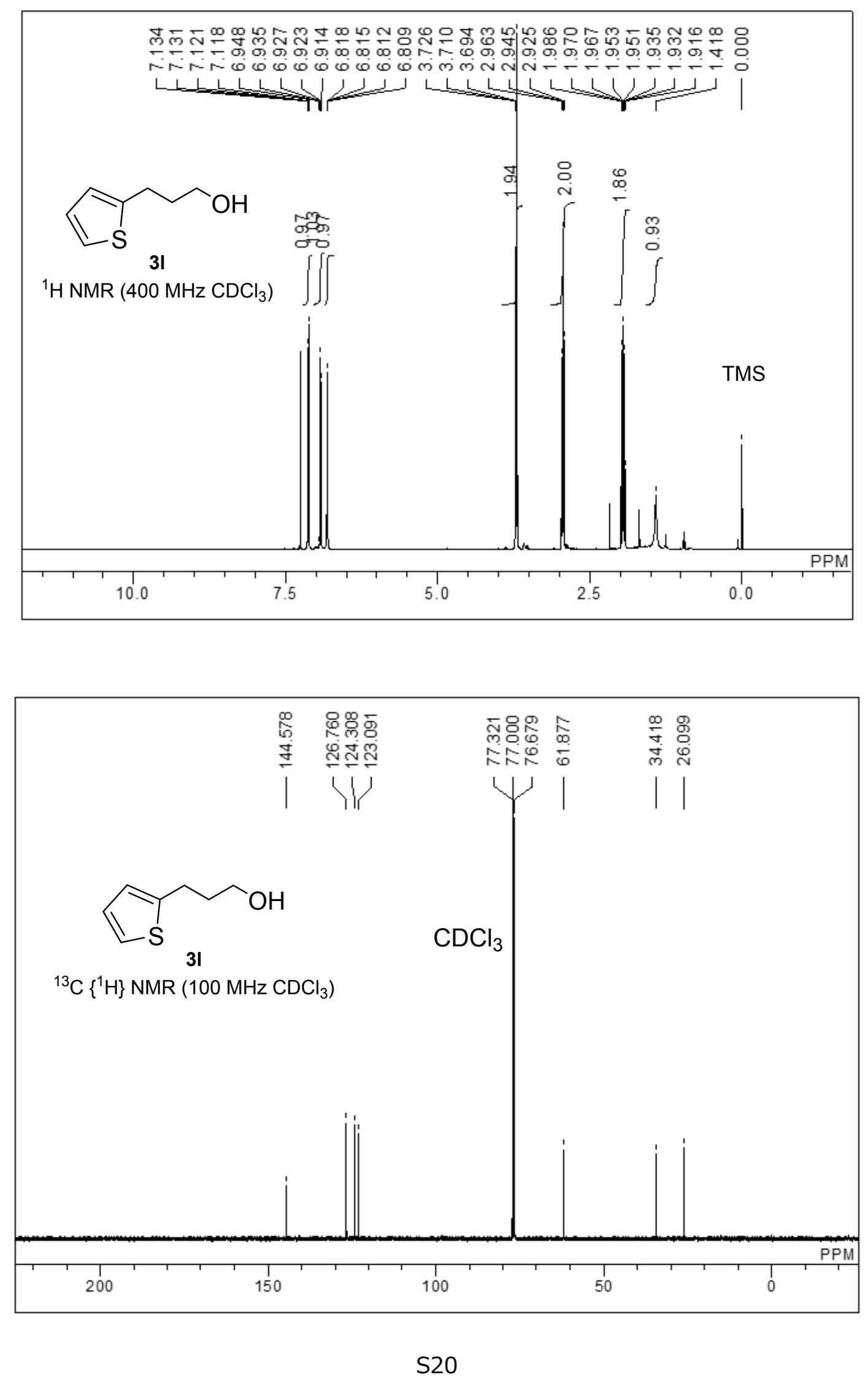

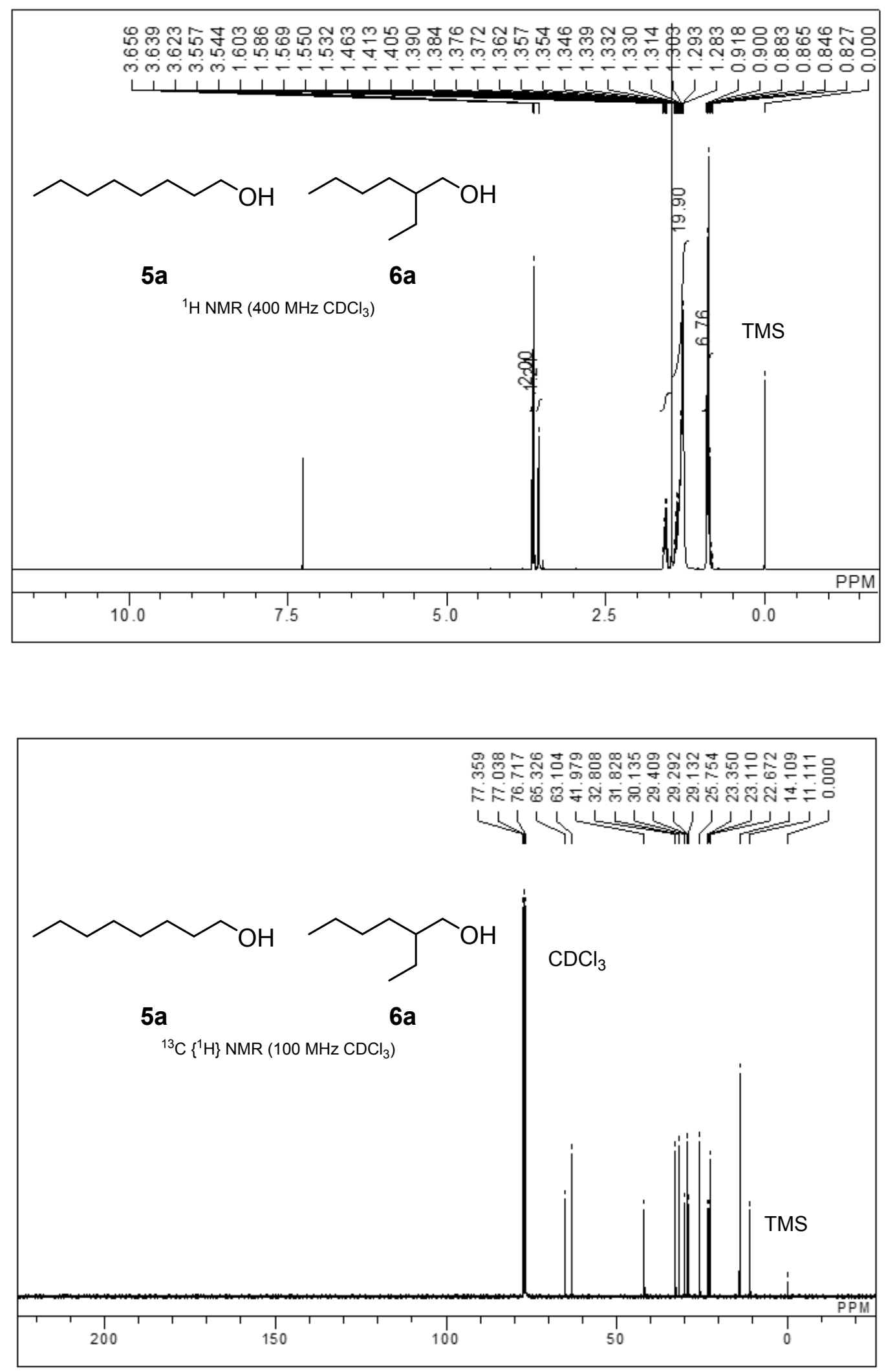

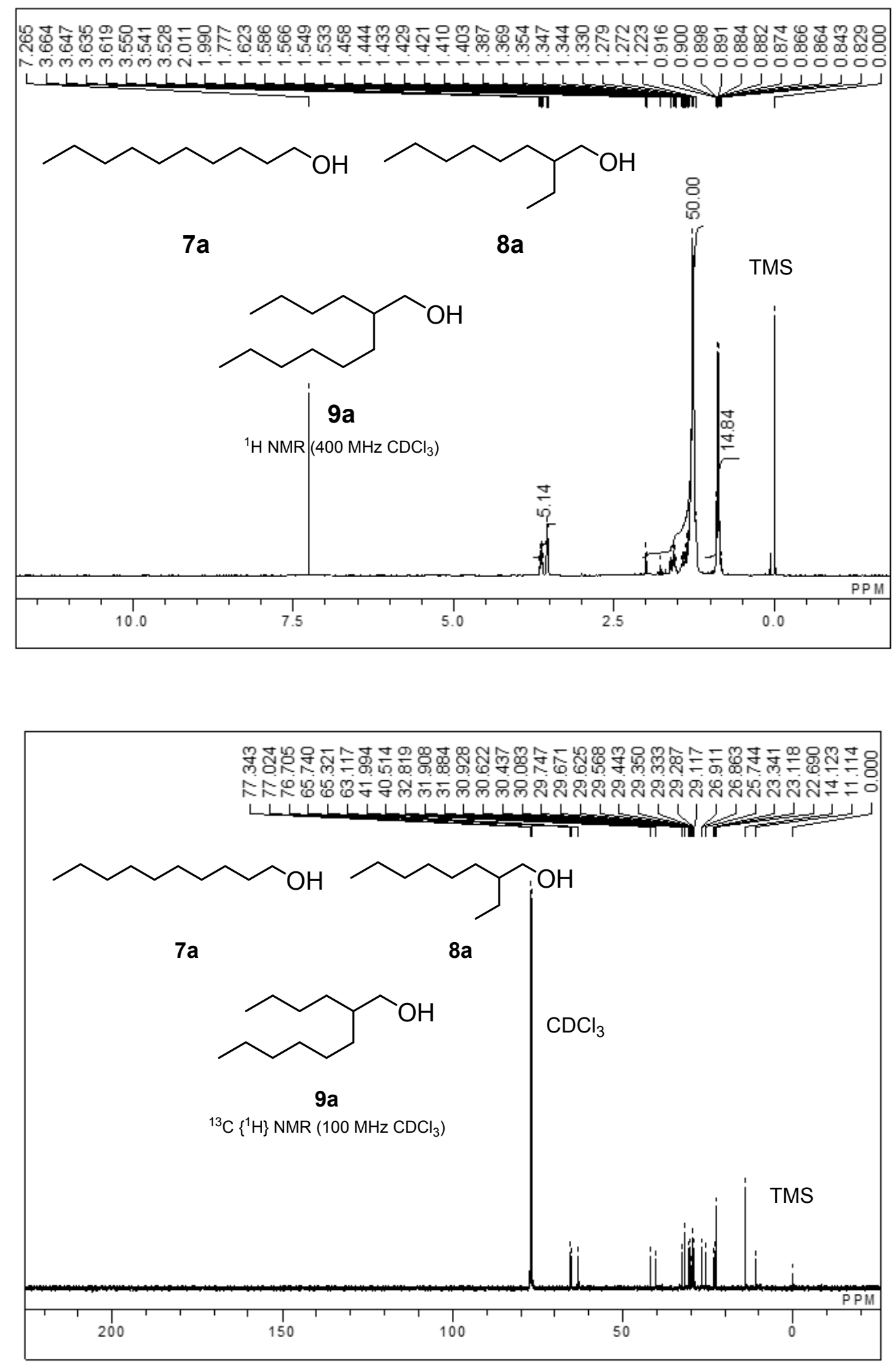

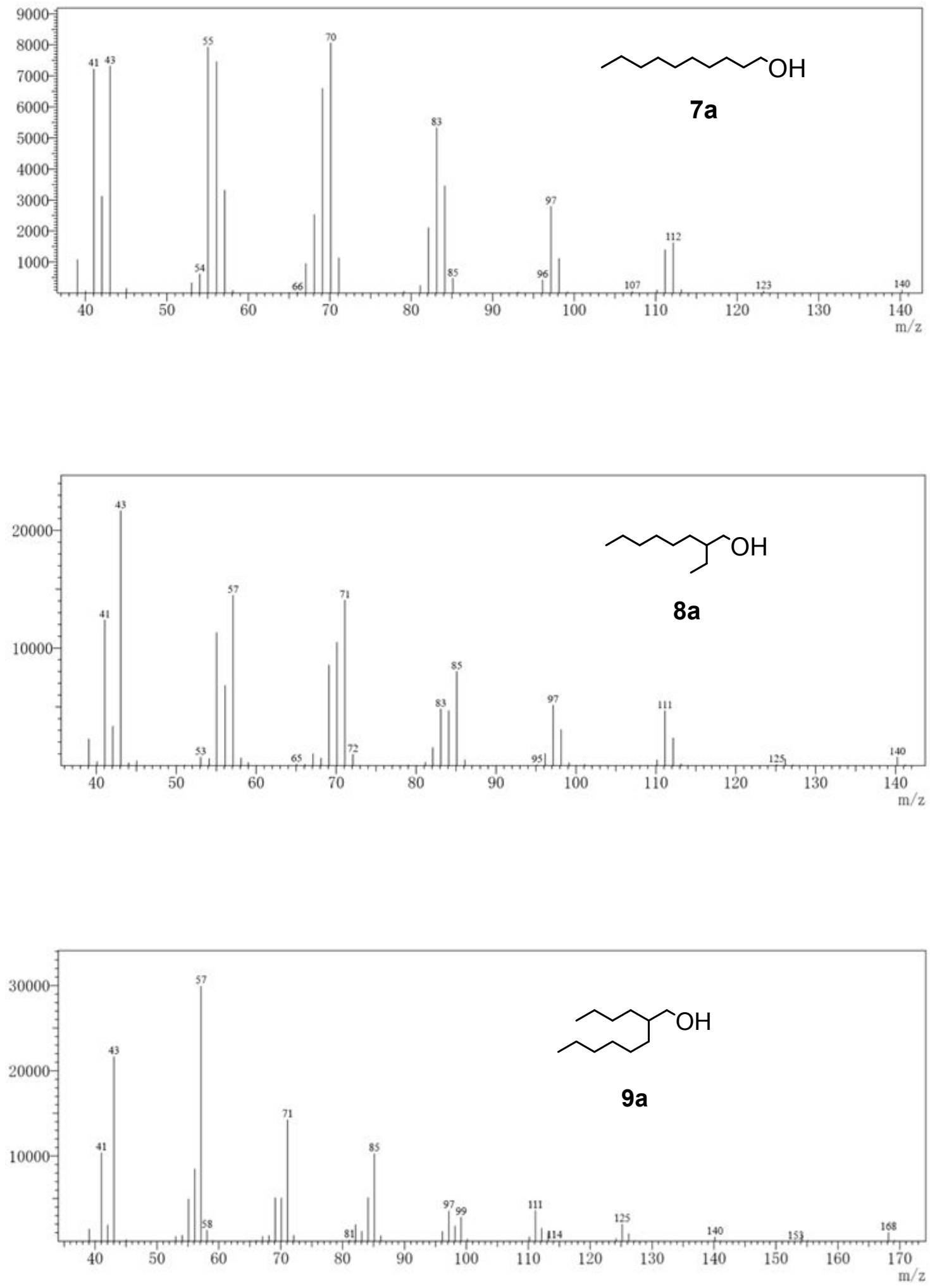

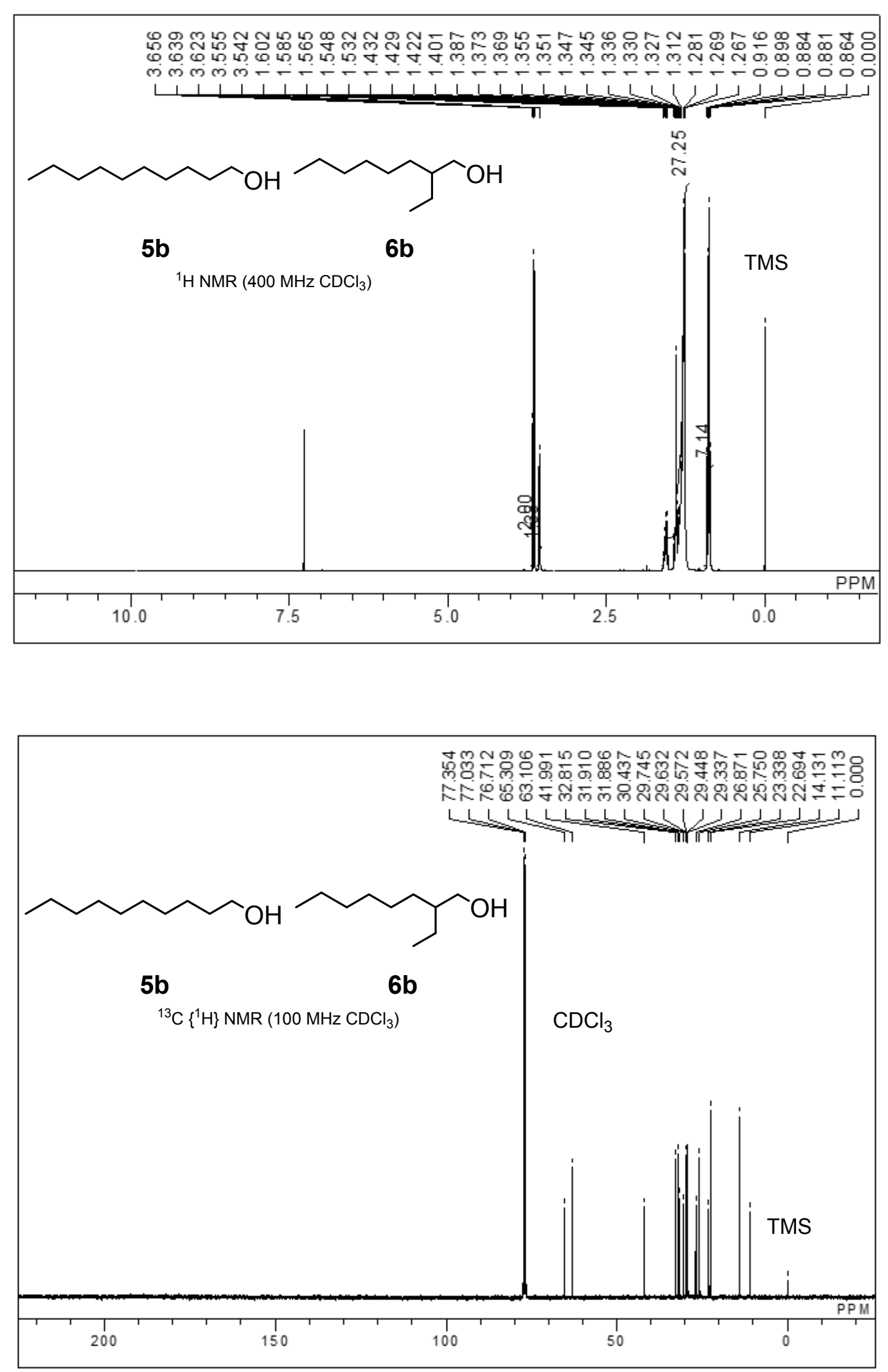

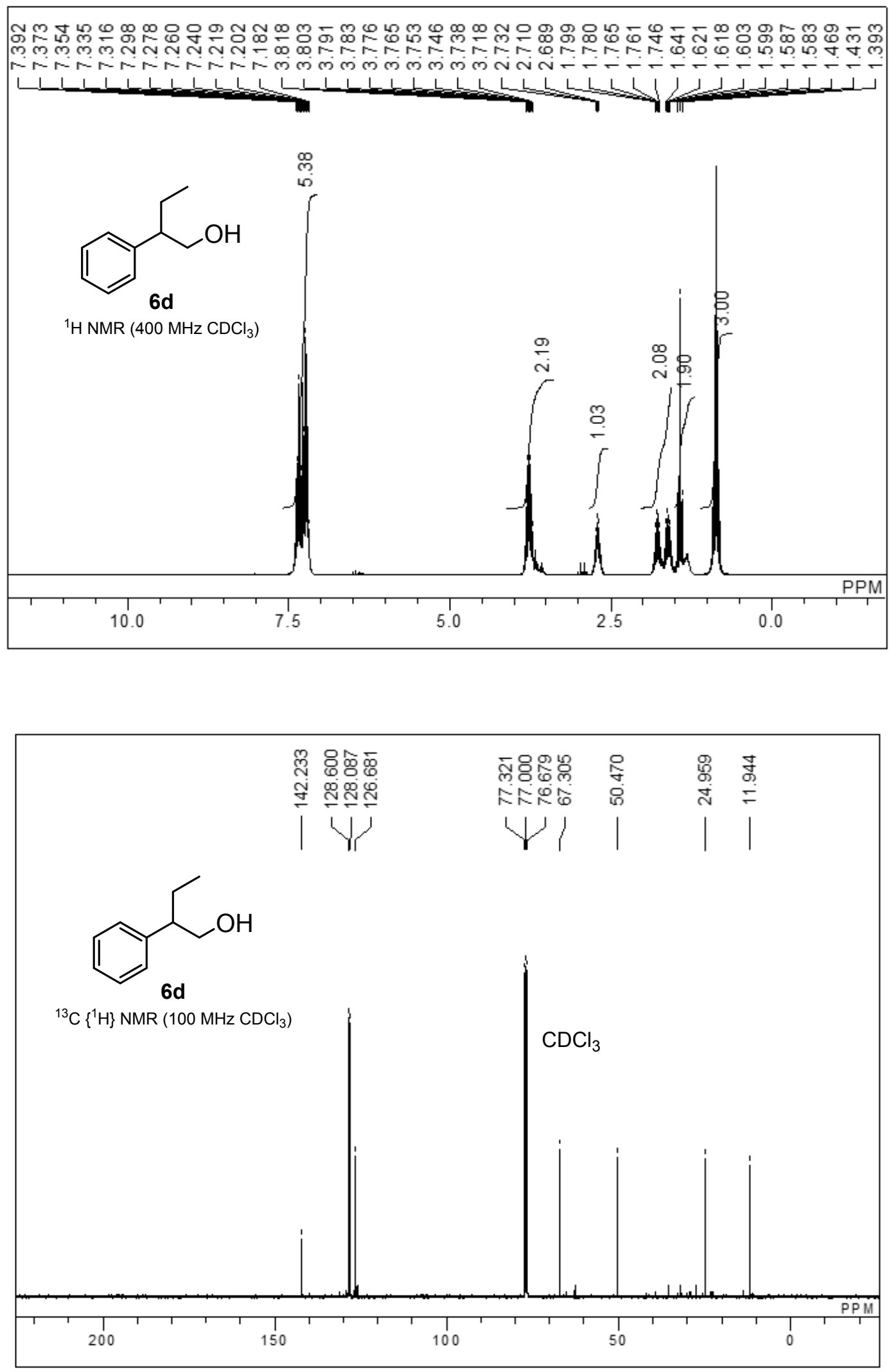

S25 

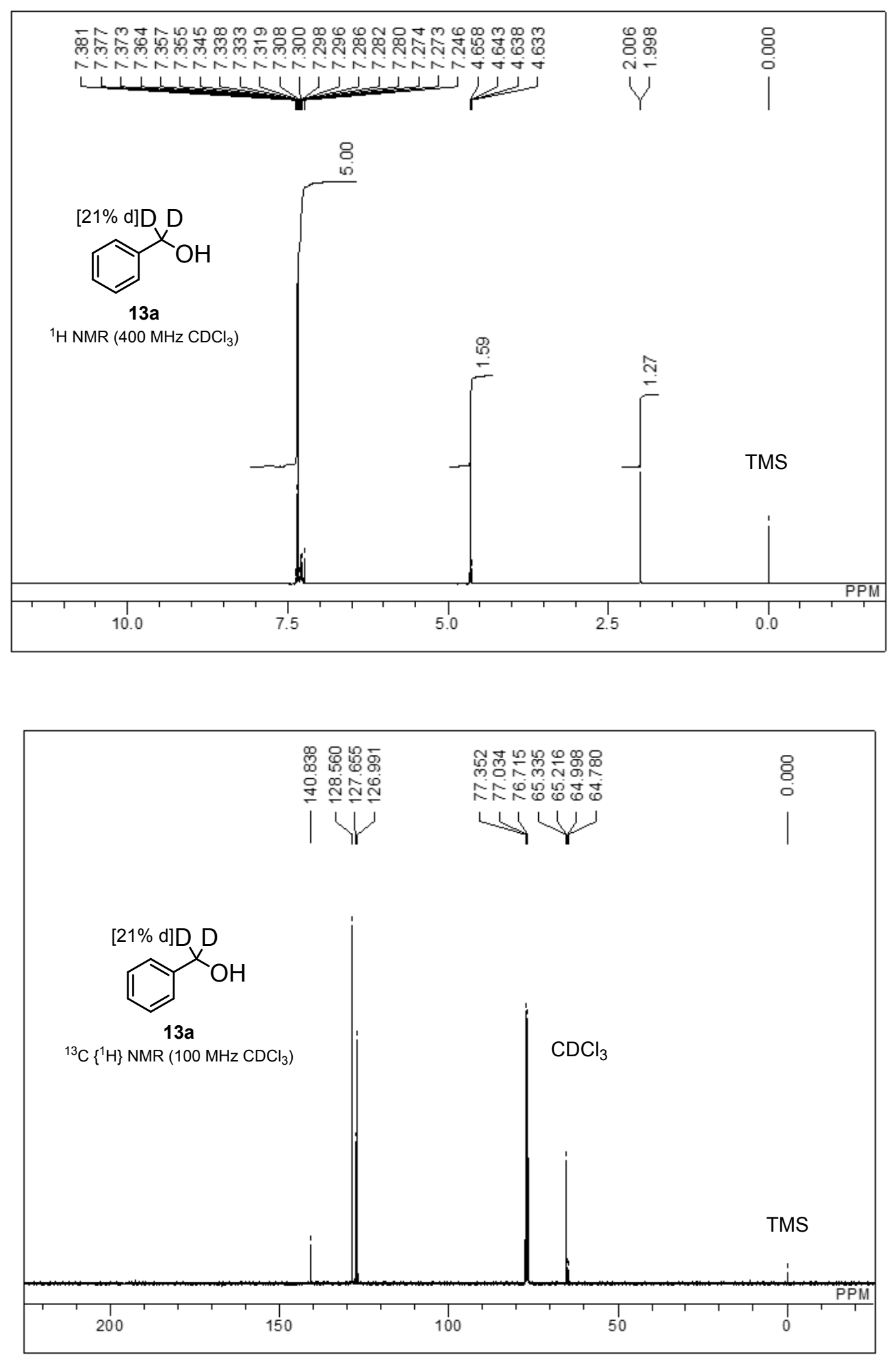

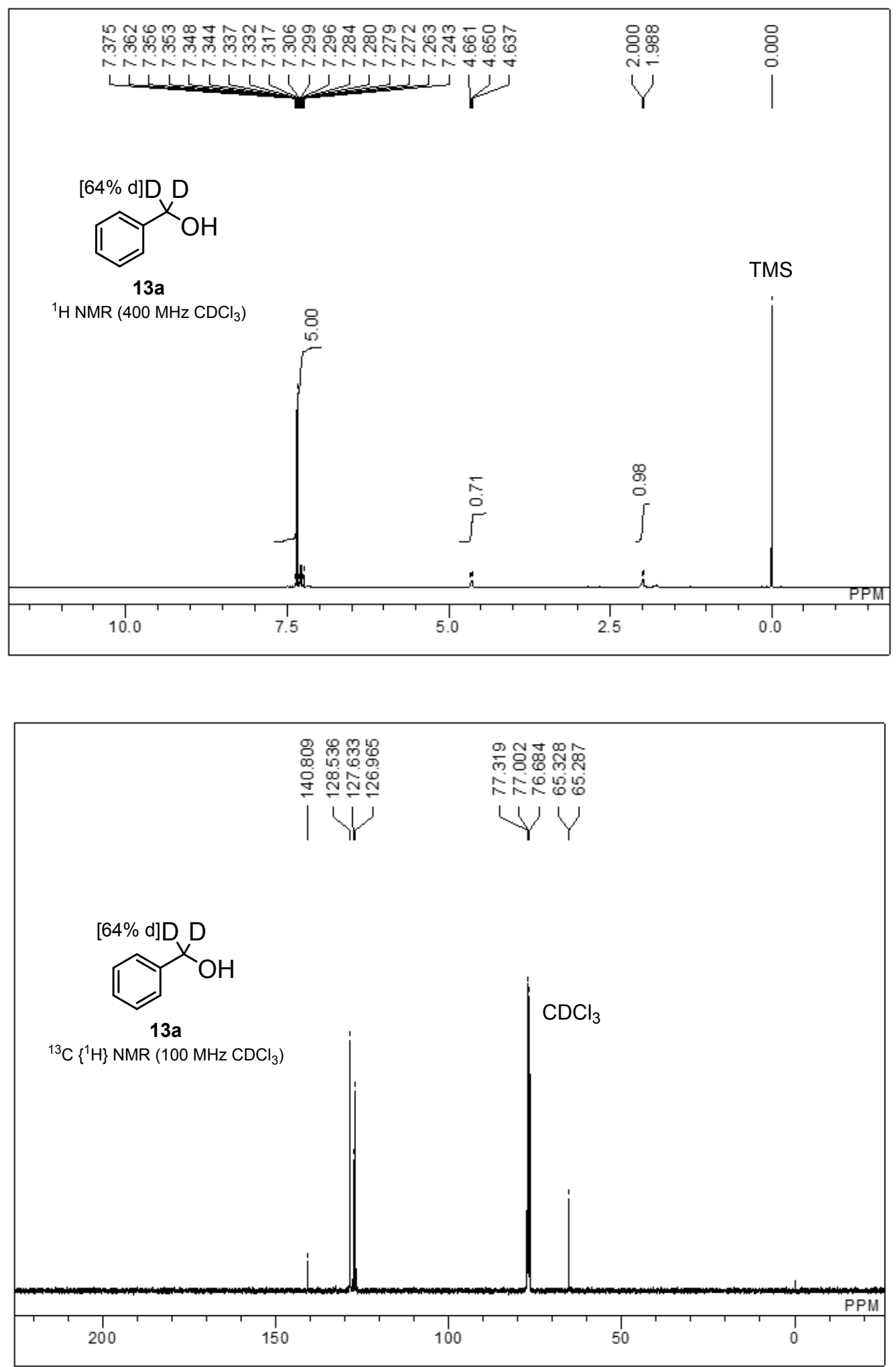

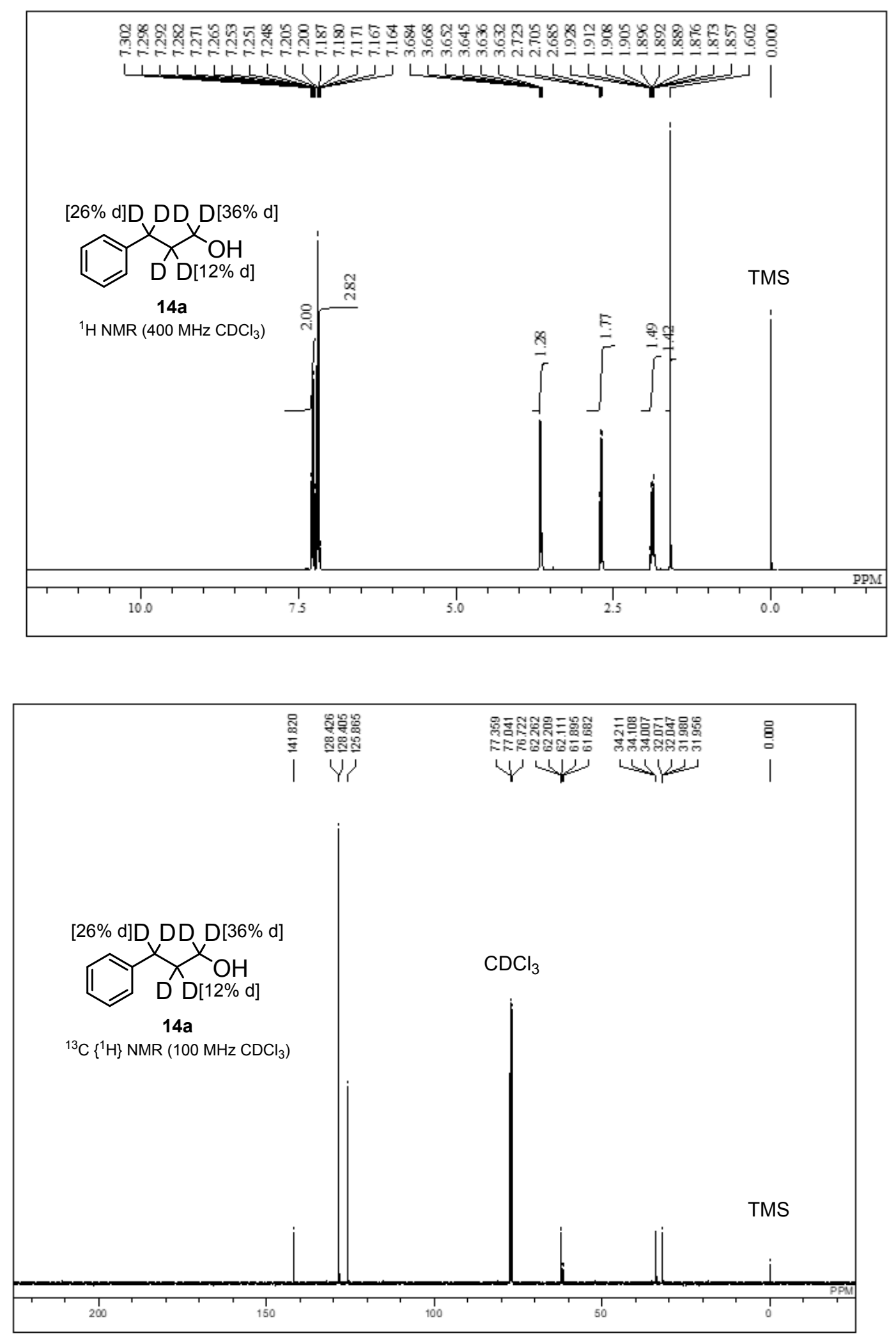

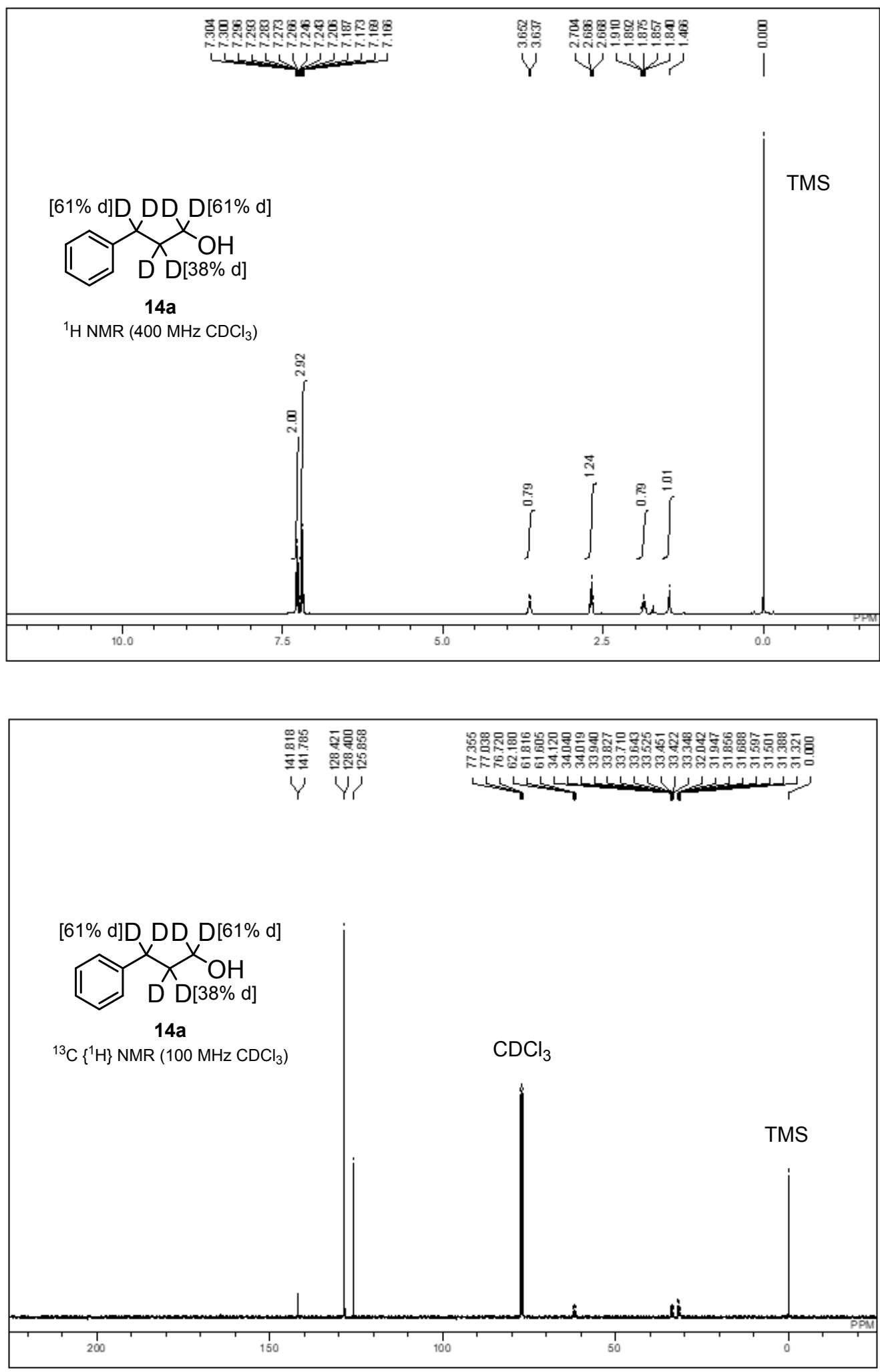